Atmos. Chem. Phys., 12, 8095-8113, 2012

www.atmos-chem-phys.net/12/8095/2012/

doi:10.5194/acp-12-8095-2012

(C) Author(s) 2012. CC Attribution 3.0 License.

\title{
Carbon and hydrogen isotopic ratios of atmospheric methane in the upper troposphere over the Western Pacific
}

\author{
T. Umezawa ${ }^{1, *}$, T. Machida ${ }^{2}$, K. Ishijima ${ }^{3}$, H. Matsueda ${ }^{4}$, Y. Sawa ${ }^{4}$, P. K. Patra ${ }^{3}$, S. Aoki ${ }^{1}$, and T. Nakazawa ${ }^{1}$ \\ ${ }^{1}$ Center for Atmospheric and Oceanic Studies, Graduate School of Science, Tohoku University, Sendai, Japan \\ ${ }^{2}$ National Institute for Environmental Studies, Tsukuba, Japan \\ ${ }^{3}$ Research Institute for Global Change, JAMSTEC, Yokohama, Japan \\ ${ }^{4}$ Meteorological Research Institute, Tsukuba, Japan \\ *now at: Max Planck Institute for Chemistry, Mainz, Germany
}

Correspondence to: T. Umezawa (taku.umezawa@mpic.de)

Received: 8 March 2012 - Published in Atmos. Chem. Phys. Discuss.: 10 April 2012

Revised: 23 August 2012 - Accepted: 25 August 2012 - Published: 10 September 2012

\begin{abstract}
We present the mixing ratio, $\delta^{13} \mathrm{C}$ and $\delta \mathrm{D}$ of atmospheric $\mathrm{CH}_{4}$ using commercial aircraft in the upper troposphere (UT) over the Western Pacific for the period December 2005-September 2010. The observed results were compared with those obtained using commercial container ships in the lower troposphere (LT) over the same region. In the Northern Hemisphere (NH), the $\mathrm{UT} \mathrm{CH}_{4}$ mixing ratio shows high values in the boreal summer-autumn, when the $\mathrm{LT} \mathrm{CH}_{4}$ mixing ratio reaches a seasonal minimum. From tagged tracer experiments made using an atmospheric chemistry transport model, we found that such high $\mathrm{CH}_{4}$ values are due to rapid transport of air masses influenced by $\mathrm{CH}_{4}$ sources in South Asia and East Asia. The observed isotopic ratio data imply that these areas have $\mathrm{CH}_{4}$ sources with relatively low $\delta^{13} \mathrm{C}$ and $\delta \mathrm{D}$ signatures such as biogenic sources. Latitudinal distributions of the annual average UT and LT $\mathrm{CH}_{4}$ mixing ratio intersect each other in the tropics; the mixing ratio value is lower in the UT than in the LT in the $\mathrm{NH}$ and the situation is reversed in the Southern Hemisphere ( $\mathrm{SH}$ ), due mainly to the $\mathrm{NH}$ air intrusion into the $\mathrm{SH}$ through the UT. Such intersection of the latitudinal distributions is observable in $\delta \mathrm{D}$ but not in $\delta^{13} \mathrm{C}$, implying an additional contribution from reaction of $\mathrm{CH}_{4}$ with active chlorine in the marine boundary layer. $\delta^{13} \mathrm{C}$ and $\delta \mathrm{D}$ show low values in the $\mathrm{NH}$ and high values in the SH both in the UT and in the LT. We also observed an increase in the $\mathrm{CH}_{4}$ mixing ratio and
\end{abstract}

decreases in $\delta^{13} \mathrm{C}$ and $\delta \mathrm{D}$ during 2007-2008 in the UT and LT over the Western Pacific, possibly due to enhanced biogenic emissions in the tropics and $\mathrm{NH}$.

\section{Introduction}

Methane $\left(\mathrm{CH}_{4}\right)$ is an important trace gas in atmospheric chemistry and climate. $\mathrm{CH}_{4}$ is emitted into the atmosphere from natural and anthropogenic sources, and it is destroyed mainly by reaction with hydroxyl radical $(\mathrm{OH})$ in the troposphere. The global average $\mathrm{CH}_{4}$ budget is relatively well constrained, for example, to be $(514 \pm 14) \mathrm{Tg} \mathrm{a}^{-1}\left(\right.$ in $^{\left.\mathrm{CH}_{4}\right)}$ of net emissions from the surface during the 2000s (Patra et al., 2011), but there are still large uncertainties in quantitative estimation of individual strengths and distributions (e.g. Forster et al., 2007). Ice core analyses revealed low $\mathrm{CH}_{4}$ levels of approximately 700 parts per billion $\left(\mathrm{ppb}=\mathrm{nmol} \mathrm{mol}^{-1}\right)$ in the pre-industrial/agricultural era, followed by rapid increase due to anthropogenic $\mathrm{CH}_{4}$ emissions (e.g. Nakazawa et al., 1993a; Etheridge et al., 1998). Systematic measurements of the atmospheric $\mathrm{CH}_{4}$ mixing ratio were initiated in the late 1970s (Blake and Rowland, 1986), and they found that atmospheric $\mathrm{CH}_{4}$ increased at rates of $10-20 \mathrm{ppb} \mathrm{a}^{-1}$ in the $1980 \mathrm{~s}$. This increase slowed greatly in the early 1990s until becoming nearly zero in 1999 , and then the $\mathrm{CH}_{4}$ mixing ratio began 
to increase again after 2007 (Dlugokencky et al., 2003, 2009; Rigby et al., 2008; Terao et al., 2011). The globally averaged $\mathrm{CH}_{4}$ mixing ratio is reported to have been $1794 \mathrm{ppb}$ in 2009 (Dlugokencky et al., 2011).

The atmospheric $\mathrm{CH}_{4}$ mixing ratio has been observed mostly at surface baseline stations (e.g. Steele et al., 1987; Cunnold et al., 2002), and the data obtained were used to provide a global picture of atmospheric $\mathrm{CH}_{4}$ variations, as well as to constrain atmospheric chemistry transport models for estimation of the global $\mathrm{CH}_{4}$ budget (e.g. Fung et al., 1991; Bousquet et al., 2006; Patra et al., 2009). However, it has been pointed out that the present observation network of atmospheric $\mathrm{CH}_{4}$ is not sufficient for describing atmospheric $\mathrm{CH}_{4}$ variations caused by regional sources (Fung et al., 1991; Chen and Prinn, 2006; Houweling et al., 2006; Bousquet et al., 2011). On the other hand, satellite observations can cover a spatially wide area at the cost of less precise individual measurements relative to the high precision of laboratorybased observations. In fact, the data from the Scanning Imaging Absorption Spectrometer for Atmospheric Chartography (SCIAMACHY) aboard the ENVISAT satellite revealed the atmospheric $\mathrm{CH}_{4}$ variations over such regions as Asia, Africa and South America where important $\mathrm{CH}_{4}$ sources exist but direct atmospheric $\mathrm{CH}_{4}$ observations are very sparse (Frankenberg et al., 2011). Data from SCIAMACHY were also used for inverse modeling to improve our knowledge of the distributions of $\mathrm{CH}_{4}$ sources (Bergamaschi et al., 2007, 2009). $\mathrm{CH}_{4}$ data by the Greenhouse gases Observing SATellite (GOSAT) are also becoming available, which are likely to constrain surface emissions at weekly to monthly time intervals (Yoshida et al., 2011). Aircraft observations using a grab sampling technique with subsequent laboratory analysis are also helpful for high-precision measurements of $\mathrm{CH}_{4}$ mixing ratio in the upper troposphere (UT). However, regular measurements using dedicated research aircraft are expensive, and the number of aircraft observations for trace gases is limited (Nakazawa et al., 1993b; Francey et al., 1999; Miller et al., 2007).

Commercial airliners have also been used for measurements of trace gases over a long distances, particularly in the UT. The Tohoku University group conducted trace gas observations on domestic and international flights by Toa Domestic Airlines (renamed Japan Air System later) and Japan Airlines (JAL) (Tanaka et al., 1983, 1987a; Nakazawa et al., 1991, 1993b; Ishijima et al., 2001, 2010). Observations of $\mathrm{CO}_{2}, \mathrm{CH}_{4}$ and $\mathrm{CO}$ in the UT over the Western Pacific were also conducted using JAL aircraft by the Meteorological Research Institute, Japan (Matsueda and Inoue 1996; Matsueda et al., 1998, 2002). This observation program has been merged into a new project named CONTRAIL (Comprehensive Observation Network for TRace gases by AILiner) (Machida et al., 2008).

Regular measurements of trace gases using commercial aircraft are also made through the CARIBIC project (Civil Aircraft for the Regular Investigation of the atmosphere
Based on an Instrument Container) (Brenninkmeijer et al., 2007). This program reported an interesting phenomenon that the mixing ratios of greenhouse gases and nonmethane hydrocarbons are high in the UT (approximately 10-12 km) over South Asia during the Asian summer monsoon season of June-September (Schuck et al., 2010; Baker et al., 2011). Such high $\mathrm{CH}_{4}$ mixing ratios were also found by satellite measurements (Park et al., 2004; Xiong et al., 2009). It is known that the Asian region (South Asia, East Asia and Southeast Asia) has important natural and anthropogenic $\mathrm{CH}_{4}$ sources including rice paddies with annual emissions of $\sim 20-50 \mathrm{Tg} \mathrm{a}^{-1}$, livestock with $\sim 26-36 \mathrm{Tg} \mathrm{a}^{-1}$, fossil fuel consumption of $\sim 10-20 \mathrm{Tg} \mathrm{a}^{-1}$ and natural wetlands of $\sim 40 \mathrm{Tg} \mathrm{a}^{-1}$ (Fung et al., 1991; Olivier and Berdowski, 2001; Yan et al., 2003; Yamaji et al., 2003; Streets et al., 2003; Xiao et al., 2004). However, since systematic observations of the $\mathrm{CH}_{4}$ mixing ratio in rapidly developing Asian countries, such as China and India, remain sparse (Lal et al., 2004; Zhou et al., 2004; Bhattacharya et al., 2009), quantitative understanding of $\mathrm{CH}_{4}$ sources in this region is insufficient.

Carbon and hydrogen isotopic ratios of $\mathrm{CH}_{4}\left(\delta^{13} \mathrm{C}\right.$ and $\left.\delta \mathrm{D}\right)$ are useful for distinguishing contributions of individual $\mathrm{CH}_{4}$ sources to atmospheric $\mathrm{CH}_{4}$ variations, since each source has its own isotopic signature, the average values of $\delta^{13} \mathrm{C}$ and $\delta \mathrm{D}$ being about -60 and $-300 \%$ for biogenic sources, -40 and $-180 \%$ for fossil fuel sources, and -25 and $-200 \%$ for biomass burning sources (Quay et al., 1999). The literatures give a range of values for the source type. Namely, for biogenic sources, previous studies give $\delta^{13} \mathrm{C}$ and $\delta \mathrm{D}$ values ranging from -80 to $-40 \%$ and -400 to $-300 \%$, respectively (e.g. Whiticar and Schaefer, 2007). For fossil fuel sources, Schoell (1980) gives values from -90 to $-30 \%$ o for $\delta^{13} \mathrm{C}$ and -280 to $-130 \%$ for $\delta \mathrm{D}$. For biomass burning sources, $\delta^{13} \mathrm{C}$ and $\delta \mathrm{D}$ range from -30 to $-16 \%$ and -330 to $-190 \%$, respectively (e.g. Yamada et al., 2006; Umezawa et al., 2011). The number of isotopic observations of atmospheric $\mathrm{CH}_{4}$ has increased since a continuousflow measurement technique with a gas-chromatograph isotope ratio mass spectrometry (GC-IRMS) became available (Rice et al., 2001; Miller et al., 2002; Umezawa et al., 2009). Measurements of $\delta^{13} \mathrm{C}$ are made at selected sites of the National Oceanic and Atmospheric Administration/Global Monitoring Division (NOAA/GMD) (Miller et al., 2002; Dlugokencky et al., 2009), Ny Ålesund, Svalbard (Morimoto et al., 2006), and two sites in the western part of the United States (Tyler et al., 2007). Tyler et al. (2007) also reported the measurement results of $\delta \mathrm{D}$. However, their systematic observations are still limited, and only campaign-based observations were made for $\delta^{13} \mathrm{C}$ and $\delta \mathrm{D}$ variations in the free troposphere (Sugawara et al., 1996; Tyler et al., 1999; Mak et al., 2000; Umezawa et al., 2011).

In order to understand spatial and temporal variations of $\delta^{13} \mathrm{C}$ and $\delta \mathrm{D}$ in the UT over the Western Pacific, we analyzed the CONTRAIL air samples for these variables, in addition to the $\mathrm{CH}_{4}$ mixing ratio. These data are available in 


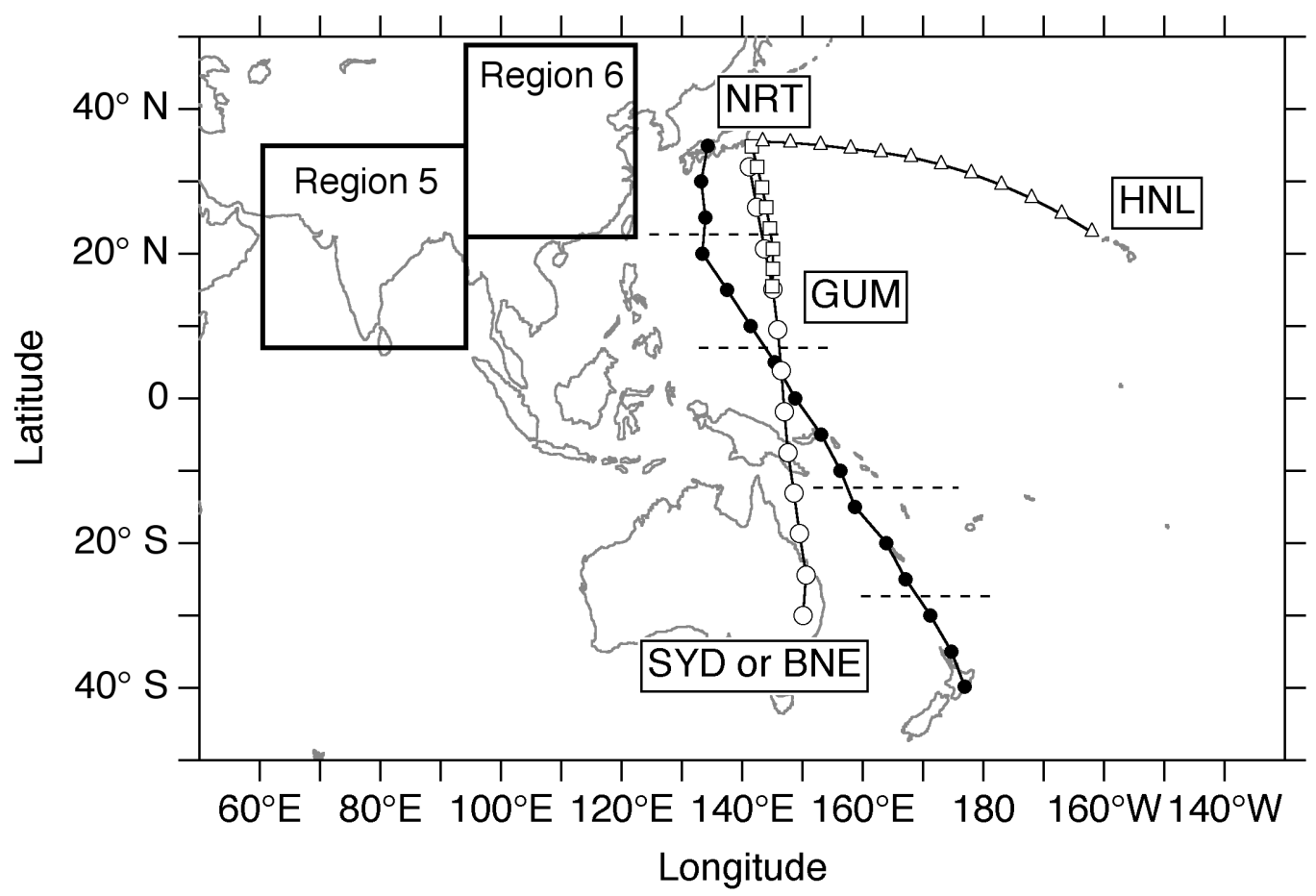

Fig. 1. A map showing locations where air samples were collected in this study. NRT: Narita, GUM: Guam, HNL: Honolulu, SYD: Sydney, BNE: Brisbane. The air sampling was made between NRT and SYD or BNE for December 2005-March 2009 (open circles), between NRT and GUM for April 2009-March 2010 (open squares) and between NRT and HNL for April-September 2010 (open triangles). Also shown are air sampling locations by container ships (closed circles). Dashed lines on the ship track represent the division of latitude bands for the data analysis (see text). Boxes denote the two regions (Region 5 and Region 6) assigned for the tagged experiments.

the Supplement and from the World Data Center for Greenhouse Gases (http://ds.data.jma.go.jp/gmd/wdcgg/). The results were compared with those observed in the lower troposphere (LT) using container ships that sailed between Japan and New Zealand in the Western Pacific, of which routes are less than $20^{\circ}$ in longitude distant from the CONTRAIL flight tracks (Fig. 1). We also made tagged tracer experiments using an atmospheric chemistry transport model to examine causes of the $\mathrm{CH}_{4}$ variations observed in the UT. In this paper, we present the results obtained from our observation and model studies, and discuss them in terms of $\mathrm{CH}_{4}$ sources and atmospheric transport.

\section{Methods}

\subsection{Air sample collection}

As part of the CONTRAIL project, Automatic air Sampling Equipment (ASE) was installed onboard a Boeing 747-400. Since details of air sampling using ASE have been described elsewhere (Machida et al., 2008; Matsueda et al., 2008), only a brief description is presented here. ASE consists of two packages and each package has six titanium sample flasks, so that 12 air samples can be collected during one flight. Each flask is cylindrical in shape with solenoid valves at both ends and an inner volume of $\sim 1.71$. The sample air was collected using the air-conditioning system of the aircraft. The air sampling procedures at each location, assigned before each flight, were automatically performed by controlling a metal bellows pump and the solenoid valves using a specially designed control unit which receives flight information from the navigation system of the aircraft. The flasks were pressurised, typically to $0.15 \mathrm{MPa}$ above the surface atmospheric pressure. Particles in the sample air were removed by using a sintered inline filter.

Figure 1 shows typical sampling locations for this study. The collection of air samples were made almost twice a month between Narita (NRT), Japan and Sydney (SYD) or Brisbane (BNE), Australia from December 2005-March 2009 and between NRT and Guam (GUM) from April 2009March 2010, and once a month between NRT and Honolulu (HNL) from April-September 2010. The departure airport in Australia was frequently changed to BNE instead of SYD after October 2007, and the sample collection at $30^{\circ} \mathrm{S}$ was temporarily terminated after September 2008. Air samplings between NRT and SYD started again in April 2011 and are ongoing. 
We also analyzed the air samples collected from onboard commercial container ships sailing between Tokyo, Japan and Sydney, or Auckland, New Zealand over periods of about 40 days. Each air sample was collected into a $550 \mathrm{ml}$ Pyrex glass flask every $5^{\circ}$ latitude, as shown in Fig. 1. Details of this observation program have been described elsewhere (Tanaka et al., 1987b; Nakazawa et al., 1992, 1997a; Morimoto et al., 2000; Ishijima et al., 2009; Yashiro et al., 2009).

\subsection{Measurement of $\mathrm{CH}_{4}$ mixing ratios}

The ASE was returned to the National Institute for Environmental Studies (NIES), Tsukuba, Japan within a day of sampling, and the mixing ratios of various trace gases, including $\mathrm{CH}_{4}$, were analyzed. The $\mathrm{CH}_{4}$ mixing ratio of each air sample was determined against the NIES- $94 \mathrm{CH}_{4}$ scale using a gas chromatograph (Agilent 5890, Agilent Technologies Inc.) equipped with a flame ionization detector (GCFID) (Tohjima et al.,2002; Machida et al.,2008). Air samples collected onboard the container ships were analyzed for the $\mathrm{CH}_{4}$ mixing ratio relative to the Tohoku University (TU) 1988 scale (Aoki et al., 1992) using a GC-FID (Agilent 6890) installed at TU (Umezawa, 2009). The analytical precision of the GC-FID for the $\mathrm{CH}_{4}$ mixing ratio was estimated to be less than $2.0 \mathrm{ppb}$ for both institutes. Comparisons of the NIES and TU scales have been made several times, and the results show that the two scales agree with each other, the differences at baseline atmospheric mixing ratio levels being less than $1 \mathrm{ppb}$. We therefore applied no corrections to the mixing ratio data reported by the two institutes.

\subsection{Measurements of $\delta^{13} \mathrm{C}$ and $\delta \mathrm{D}$}

For analysis, an aliquot of each ASE air sample was transferred into two evacuated $100 \mathrm{ml}$ sample flasks at NIES, and the flasks were sent to TU for $\delta^{13} \mathrm{C}$ and $\delta \mathrm{D}$ measurements. At $\mathrm{TU}$, the air sample in each flask was further divided in two for duplicate analyses of $\delta^{13} \mathrm{C}$ or $\delta \mathrm{D}$. The air samples from the container ships were also divided by the same procedure as above to allow duplicate analyses of $\delta^{13} \mathrm{C}$ and $\delta \mathrm{D}$.

Since details of our $\delta^{13} \mathrm{C}$ and $\delta \mathrm{D}$ analyses, using a gas chromatograph combustion/pyrolysis isotope ratio mass spectrometer (GC-C/P-IRMS) have been reported (Umezawa et al., 2009), only a brief description is presented here. The air sample in the $100 \mathrm{ml}$ flask was flushed by pure helium into a $\mathrm{CH}_{4}$ preconcentration trap containing HayeSep D maintained at $-130^{\circ} \mathrm{C}$ and then warmed to $-83^{\circ} \mathrm{C}$ to release simultaneously trapped gases such as $\mathrm{N}_{2}$. The trapped $\mathrm{CH}_{4}$ was transferred into a cryofocusing trap (CP-PoraBOND Q) kept at $-196{ }^{\circ} \mathrm{C}$. The concentrated $\mathrm{CH}_{4}$ was released into a PoraPLOT Q column for separation from the residual gas components. Then $\mathrm{CH}_{4}$ was combusted into $\mathrm{CO}_{2}$ at $940{ }^{\circ} \mathrm{C}$ or pyrolyzed into $\mathrm{H}_{2}$ at $1450^{\circ} \mathrm{C}$ for the subsequent continuous flow mass spectrometer measurements of $\delta^{13} \mathrm{C}$ and $\delta \mathrm{D}$, respectively, using ThermoQuest/Finnigan Delta Plus XP.
The analytical precision was estimated to be $0.08 \%$ of $\delta^{13} \mathrm{C}$ and $2.2 \%$ for $\delta \mathrm{D}$. $\delta^{13} \mathrm{C}$ and $\delta \mathrm{D}$ values in this study are reported relative to the international standards of the Vienna Peedee Belemnite (V-PDB) and the Vienna Standard Mean Ocean Water (V-SMOW), respectively.

To verify the long-term stability of our $\delta^{13} \mathrm{C}$ and $\delta \mathrm{D}$ measurements, we analyzed an aliquot of "test gas" at least twice on every measurement day. The test gas is dry natural air in a 471 aluminum cylinder. The $\mathrm{CH}_{4}$ mixing ratio, $\delta^{13} \mathrm{C}$ and $\delta \mathrm{D}$ of the test gas were determined to be $(1876 \pm 1.1) \mathrm{ppb}$, $(-47.07 \pm 0.06) \%$ and $(-98.8 \pm 2.1) \%$, respectively; the mixing ratio was determined using the GC-FID at TU relative to the TU scale, and the $\delta^{13} \mathrm{C}$ and $\delta \mathrm{D}$ values were determined from replicate measurements using the GC-C/P-IRMS against our laboratory standards of pure $\mathrm{CO}_{2}$ and $\mathrm{H}_{2}$ stored in high-pressure cylinders when the system was quite stable. The $\mathrm{CO}_{2}$ and $\mathrm{H}_{2}$ standards were calibrated using dual-inlet mass spectrometers against the V-PDB and V-SMOW, respectively (Umezawa et al., 2009). It should be noted that our $\delta^{13} \mathrm{C}$ and $\delta \mathrm{D}$ scales do not follow the "identical treatment" principle (Werner and Brand, 2001), since its experimental set up is not available yet in our laboratory. Intercomparisons of $\delta^{13} \mathrm{C}$ and $\delta \mathrm{D}$ scales with other laboratories are also needed. The measured $\delta^{13} \mathrm{C}$ value of the test gas was stable to be $(-47.12 \pm 0.10) \%$ o from the start date of our measurement until April 2008. Afterward, the measured value suddenly shifted to $(-46.85 \pm 0.09) \%$ o, keeping the same precision as before. The cause is still unclear, since we had not changed any measurement settings. To keep data consistency, we added $-0.27 \%$ o to the measured values after the gap. With regard to the stability of our $\delta \mathrm{D}$ measurements, measured values determined by our GC-C/P-IRMS system are dependent on the pyrolysis condition (Umezawa et al., 2009). As described by Bock et al. (2010) and Brass and Röckmann (2010), the pyrolysis reactor is well conditioned when carbon layer is deposited on the inner wall of the ceramic tube by passing a sufficient amount of $\mathrm{CH}_{4}$ through the reactor, and such a good condition continues until micro-fractures occur on the tube. Using the average measured value of the test gas on each measurement day, the assigned value of standard $\mathrm{H}_{2}$ was corrected so that the $\delta \mathrm{D}$ value of the test gas was constant.

Our system shows a linear response to both $\delta^{13} \mathrm{C}$ and $\delta \mathrm{D}$ as long as an air sample with a sufficient amount of $\mathrm{CH}_{4}$ is analyzed (Umezawa et al., 2009), which was confirmed by changing the volume of sample air with a constant $\mathrm{CH}_{4}$ mixing ratio. Additional tests revealed that measured values are invariable if the peak heights of the IRMS chromatogram are higher than 3.0 and $2.5 \mathrm{~V}$ for $\delta^{13} \mathrm{C}$ and $\delta \mathrm{D}$, respectively. The respective threshold peak heights for $\delta^{13} \mathrm{C}$ and $\delta \mathrm{D}$ correspond to about 800 and $1100 \mathrm{ppb}$ in sample air of $100 \mathrm{ml}$, although we have not made any tests in which the $\mathrm{CH}_{4}$ mixing ratio is changed for a constant volume sample. At this moment, it is difficult for us to assess the mixing ratio effect on the measured isotopic ratios, since standard air with different 
$\mathrm{CH}_{4}$ mixing ratios but the same isotopic value are needed. However, all measurements reported in this study were obtained under higher $\mathrm{CH}_{4}$ mixing ratios (or peak heights) than the above-mentioned thresholds, we made no corrections of the mixing ratio effect on the measured isotopic ratios.

Analyses of the $\mathrm{CH}_{4}$ mixing ratio were made for all air samples collected from the aircraft and container ships, while $\delta^{13} \mathrm{C}$ and $\delta \mathrm{D}$ were analyzed for selected samples, since their analyses are time consuming. Although the air sampling with ASE was made twice a month between NRT and SYD or BNE and between NRT and GUM, one of the two sets of samples was analyzed for each month. The air samples were collected onboard the container ships every $5^{\circ}$ latitude, but the isotope analysis was made on the samples at $\sim 10^{\circ}$ latitude interval.

\subsection{Data analysis}

To extract a long-term trend and a seasonal cycle from temporally discrete $\mathrm{CH}_{4}$ mixing ratio data, $\delta{ }^{13} \mathrm{C}$ and $\delta \mathrm{D}$, a digital filtering technique (Nakazawa et al., 1997b) was applied. The technique consists of stepwise calculation process involving linear interpolation, Reinsch-type cubic splines, Fourier harmonics and a Butterworth filter. In this study, the Butterworth filter with a cutoff period of 24 months was used to derive the long-term trend, and the average seasonal cycle was expressed by fundamental and its first harmonics. Signals with periods of 4-24 months, obtained by further applying the Butterworth filter with a cutoff period of 4 months, were defined as short-term variations. The best-fit curve to the observed data was obtained by summing the long-term trend, the average seasonal cycle and the short-term variations.

Since the numbers of $\delta^{13} \mathrm{C}$ and $\delta \mathrm{D}$ data taken in the LT are limited, we classified them into five latitudinal bands of $35^{\circ}-25^{\circ} \mathrm{N}, 20^{\circ}-10^{\circ} \mathrm{N}, 5^{\circ} \mathrm{N}-10^{\circ} \mathrm{S}, 15^{\circ}-25^{\circ} \mathrm{S}$ and $30^{\circ}-$ $40^{\circ} \mathrm{S}$ (Fig. 1) and then applied the curve fitting to the data sets of the respective bands. Since the original air samplings were made at intervals of $5^{\circ}$ latitude and every sample was analyzed for the $\mathrm{CH}_{4}$ mixing ratio, we inspected the $\mathrm{CH}_{4}$ mixing ratio data taken at individual sampling latitudes from $35^{\circ} \mathrm{N}$ to $40^{\circ} \mathrm{S}$. After that, these latitude bands were determined by carefully inspecting the average seasonal cycles of the $\mathrm{CH}_{4}$ mixing ratio at the respective latitudes, so that the seasonal $\mathrm{CH}_{4}$ features are similar within each band. On the other hand, the curve fitting method was simply applied to individual UT data sets at the assigned sampling latitudes.

\subsection{Tagged tracer simulations}

To examine where the $\mathrm{CH}_{4}$ sources contributing to $\mathrm{CH}_{4}$ variations in the UT are located, we made tagged tracer experiments using the CCSR (Center for Climate System Research)/NIES/FRCGC (Frontier Research Center for Global Change) Atmospheric General Circulation Modelbased Chemistry Transport Model (ACTM) for $\mathrm{CH}_{4}$ mix-
Table 1. Regions assigned for tagged tracer experiments.

\begin{tabular}{ll}
\hline No. & Region \\
\hline 1 & Europe \\
2 & Western Siberia \\
3 & Eastern Siberia \\
4 & Middle East \\
5 & South Asia \\
6 & East Asia \\
7 & Japan and Korea \\
8 & Southeast Asia \\
9 & Maritime Continent \\
10 & Africa \\
11 & Australia and New Zealand \\
12 & Boreal North America \\
13 & Temperate North America \\
14 & South America \\
15 & Others \\
\hline
\end{tabular}

ing ratios (Patra et al., 2009). In order to discriminate $\mathrm{CH}_{4}$ emitted from different source regions, the original surface flux field was divided into 15 regions on the globe (Table 1), and each $\mathrm{CH}_{4}$ tracer was simulated separately with each flux field. We confirmed that the sum of the 15 tracers and the simulated mixing ratio with original global flux field agreed with each other within $0.1 \%$. The original surface $\mathrm{CH}_{4}$ fluxes were prepared by multiplying optimal scaling factors to natural/biogenic emissions from the Goddard Institute for Space Studies (GISS) (Fung et al., 1991; Matthews and Fung, 1987), as well as to anthropogenic/industrial emissions from the Emission Database for Global Atmospheric Research (EDGAR, version 3.2) inventory (Olivier and Berdowski, 2001). It was assumed that atmospheric $\mathrm{CH}_{4}$ is destroyed by reacting with $\mathrm{OH}, \mathrm{Cl}$ and $\mathrm{O}\left({ }^{1} \mathrm{D}\right)$ during transport, and the mixing ratios of the reactants were prescribed by independent modeling results (Sudo et al., 2002; Takigawa et al., 1999). The natural emissions and chemical losses of $\mathrm{CH}_{4}$ varied seasonally but their seasonality was repeated annually. The anthropogenic $\mathrm{CH}_{4}$ emissions were provided by extrapolating the EDGAR inventories. Consequently, the global $\mathrm{CH}_{4}$ emission for the observation period (2007-2010) was given to be constant $\left((543 \pm 0.6) \mathrm{Tg} \mathrm{a}^{-1}\right)$. The model meteorological field was nudged to Japanese 25-year ReAnalysis (JRA25) (Onogi et al., 2007) and thus interannually variable. Patra et al. (2009) showed that the $\mathrm{CH}_{4}$ mixing ratio variations observed at surface baseline sites around the world are reproduced relatively well by using this model. The hourly model outputs were sampled for the times and locations specified by our observations, to compare directly with the observational results. 


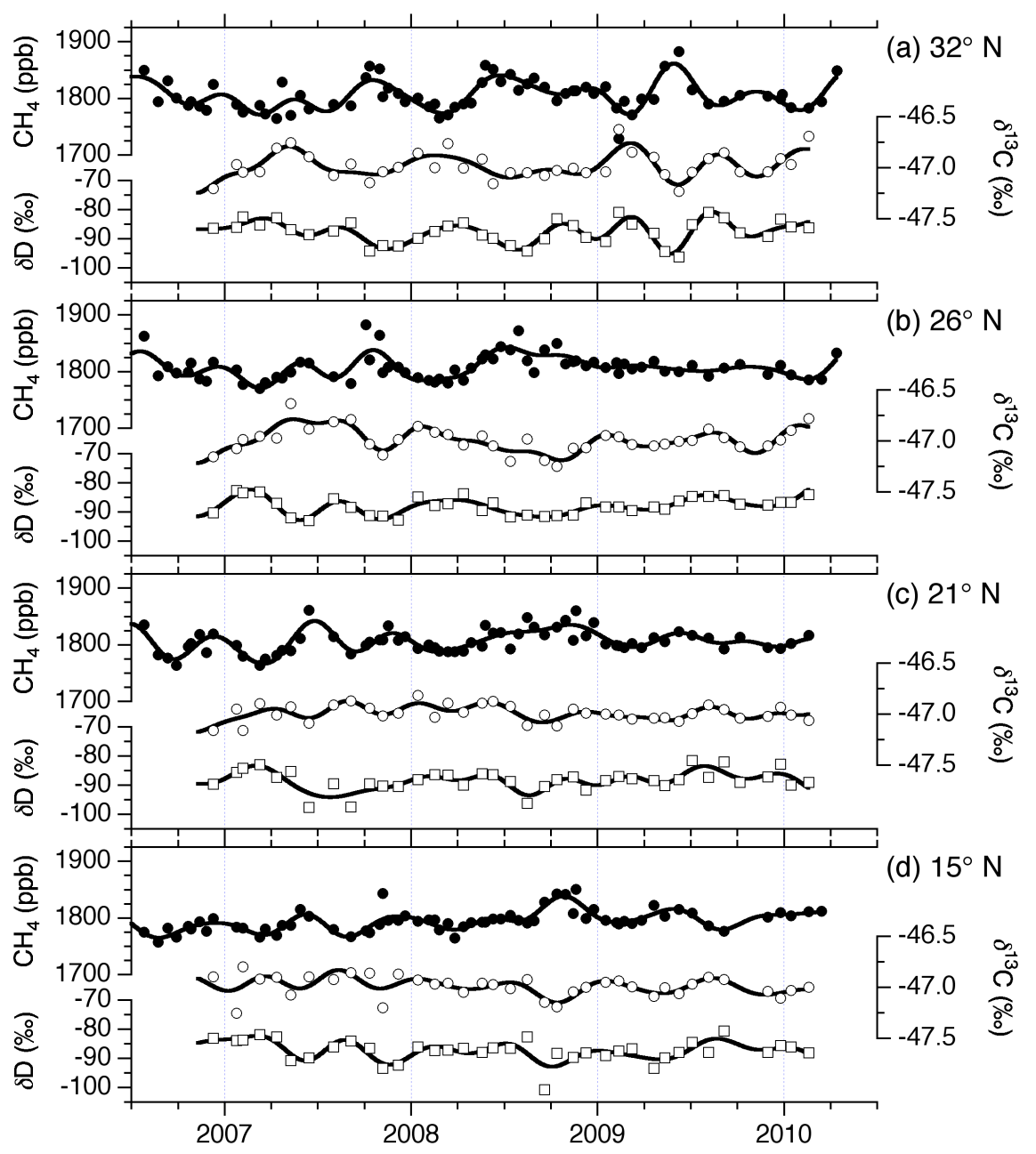

Fig. 2. Temporal variations of the $\mathrm{CH}_{4}$ mixing ratio (closed circles), $\delta^{13} \mathrm{C}$ (open circles) and $\delta \mathrm{D}$ (open squares) in the UT at (a) $32^{\circ} \mathrm{N}$, (b) $26^{\circ} \mathrm{N}$, (c) $21^{\circ} \mathrm{N}$ and (d) $15^{\circ} \mathrm{N}$ in the UT between Australia and Japan and between Japan and Guam. Also shown are the best-fit curves to the observed data (solid lines).

\section{Results and discussions}

\subsection{Variations of atmospheric $\mathrm{CH}_{4}$ and its isotopes in the UT}

Figure 2 shows time series of the $\mathrm{CH}_{4}$ mixing ratio, $\delta^{13} \mathrm{C}$ and $\delta \mathrm{D}$ obtained in the UT between NRT and Australia (SYD or BNE) and between NRT and GUM. For time series obtained between $32^{\circ}$ and $15^{\circ} \mathrm{N}$, high $\mathrm{CH}_{4}$ mixing ratios often appear in boreal summer-autumn, and relatively low $\mathrm{CH}_{4}$ mixing ratios are found in winter-spring (Fig. 3a). Such summer-autumn $\mathrm{CH}_{4}$ mixing ratios are higher by as much as $30-80 \mathrm{ppb}$ than the winter-spring mixing ratios. The low $\mathrm{CH}_{4}$ mixing ratios observed in winter-spring may be partly attributable to an intrusion of stratospheric air with low $\mathrm{CH}_{4}$ mixing ratios into the troposphere (e.g. Sugawara et al., 1997). A similar phenomenon was also found for the $\mathrm{N}_{2} \mathrm{O}$ mixing ratio at $32^{\circ} \mathrm{N}$ from the same ASE samples (Ishijima et al., 2010). In general, $\delta^{13} \mathrm{C}$ and $\delta \mathrm{D}$ at latitudes between $32^{\circ} \mathrm{N}$ and $15^{\circ} \mathrm{N}$ show a negative correlation with the $\mathrm{CH}_{4}$ mixing ratio; high and low values of $\delta^{13} \mathrm{C}$ and $\delta \mathrm{D}$ are observable in winter-spring and autumn, respectively (Fig. $3 \mathrm{~b}$ and c). The most compact relationships between the isotopic ratios and the $\mathrm{CH}_{4}$ mixing ratio were found at $32^{\circ} \mathrm{N}$ with correlation coefficients $R$ of -0.75 for $\delta^{13} \mathrm{C}$ and -0.77 for $\delta \mathrm{D}$, and the corresponding coefficients are -0.61 and -0.60 at $26^{\circ} \mathrm{N},-0.44$ and -0.51 at $21^{\circ} \mathrm{N}$, and -0.63 and -0.61 at $15^{\circ} \mathrm{N}$.

There are some studies that observed high summerautumn $\mathrm{CH}_{4}$ mixing ratios in the UT in the $\mathrm{NH}$ mid-latitudes. Matsueda and Inoue (1996) reported, from their $\mathrm{CH}_{4}$ measurements in the UT between Cairns, Australia and NRT during 1993-1994, that in boreal autumn, high $\mathrm{CH}_{4}$ mixing ratios appear in the $\mathrm{NH}$, but the feature disappears moving southward. Schuck et al. (2010) also found high $\mathrm{CH}_{4}$ mixing ratios in the UT around $20^{\circ}-40^{\circ} \mathrm{N}$ in eastern South 


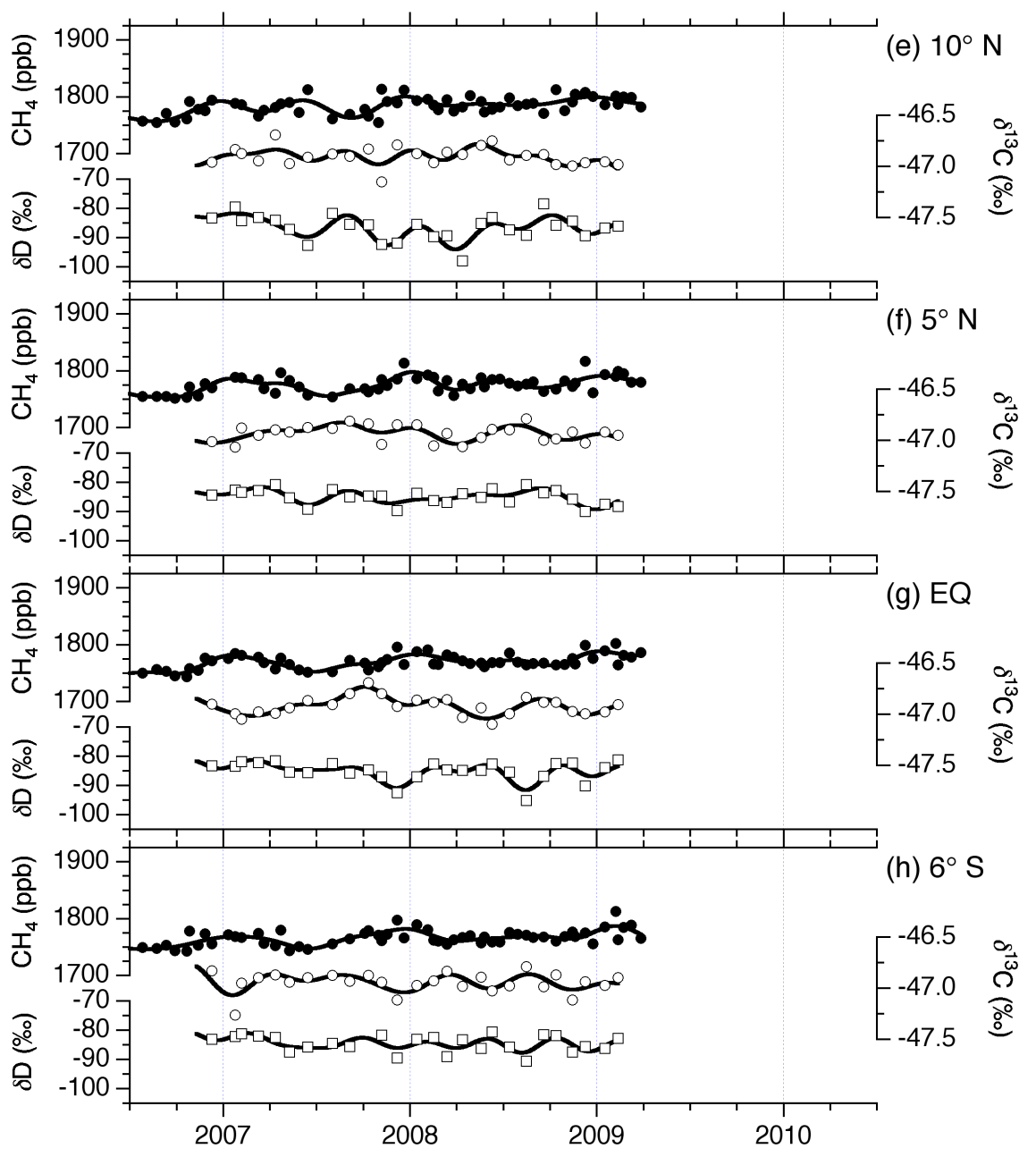

Fig. 2. Same as Fig. $2 \mathrm{a}-\mathrm{d}$, but for (e) $10^{\circ} \mathrm{N}$, (f) $5^{\circ} \mathrm{N}$, (g) the equator and (h) $6^{\circ} \mathrm{S}$ between Australia and Japan.

Asia during June-September 2008. Furthermore, the Atmospheric Infrared Sounder (AIRS) instrument onboard the EOS/Aqua satellite observed high $\mathrm{CH}_{4}$ mixing ratios at 150 $300 \mathrm{hPa}$ levels over northern South Asia for July-September with maximum in an early September (Xiong et al., 2009). Measurements over geographically wide area were made by the Halogen Occultation Experiment (HALOE) instrument onboard the Upper Atmosphere Research Satellite (UARS) spacecraft (Park et al., 2004), and their results revealed that high $\mathrm{CH}_{4}$ mixing ratios appear at $136 \mathrm{hPa}$ level at $10^{\circ}-40^{\circ} \mathrm{N}$ during June-September, especially in South Asia. These previous studies suggest that boundary layer air affected by various $\mathrm{CH}_{4}$ sources in the Asian region is transported into the UT and responsible for the high $\mathrm{CH}_{4}$ mixing ratios in summer.

The high $\mathrm{CH}_{4}$ mixing ratio values observed in the $\mathrm{NH}$ in boreal summer-autumn become unclear going southward, and in the tropics the $\mathrm{CH}_{4}$ mixing ratios shows slightly higher and lower values in boreal winter-spring and summer-autumn, respectively (Figs. 2e-h and Fig. 3a).
The peak-to-peak amplitude of the seasonal $\mathrm{CH}_{4}$ cycle is about $30 \mathrm{ppb}$ at $10^{\circ} \mathrm{N}$ and $5^{\circ} \mathrm{N}$ and $15 \mathrm{ppb}$ at the equator and $6^{\circ} \mathrm{S}$, indicating a southward reduction of the seasonal cycle of $\mathrm{CH}_{4}$ fluxes. In the $\mathrm{SH}$, the seasonal $\mathrm{CH}_{4}$ cycles are much reduced, and its seasonal minimum and maximum appear in the austral summer (December-January) and spring (September-October), respectively (Fig. 3a). The $\mathrm{CH}_{4}$ seasonality observed in the SH UT is generally consistent with that observed using aircraft over Cape Grim, Australia (Francey et al., 1999), as well as with zonal-mean seasonal cycle reported from satellite observations (Park et al., 2004). It should be noted that Ishijima et al. (2010) found low $\mathrm{N}_{2} \mathrm{O}$ mixing ratios at $30^{\circ} \mathrm{S}$ in the austral spring, due to an intrusion of the stratospheric air into the UT, but the limited number of such stratospheric samples has an insignificant effect on the seasonal $\mathrm{CH}_{4}$ cycle at this latitude.

While $\delta^{13} \mathrm{C}$ and $\delta \mathrm{D}$ vary seasonally in opposite phase with the $\mathrm{CH}_{4}$ mixing ratio in the $\mathrm{NH}\left(32^{\circ}-10^{\circ} \mathrm{N}\right)$, their seasonal cycles are rather irregular in the tropics $\left(5^{\circ} \mathrm{N}\right.$ and the equator), resulting in even poorer negative correlations with 


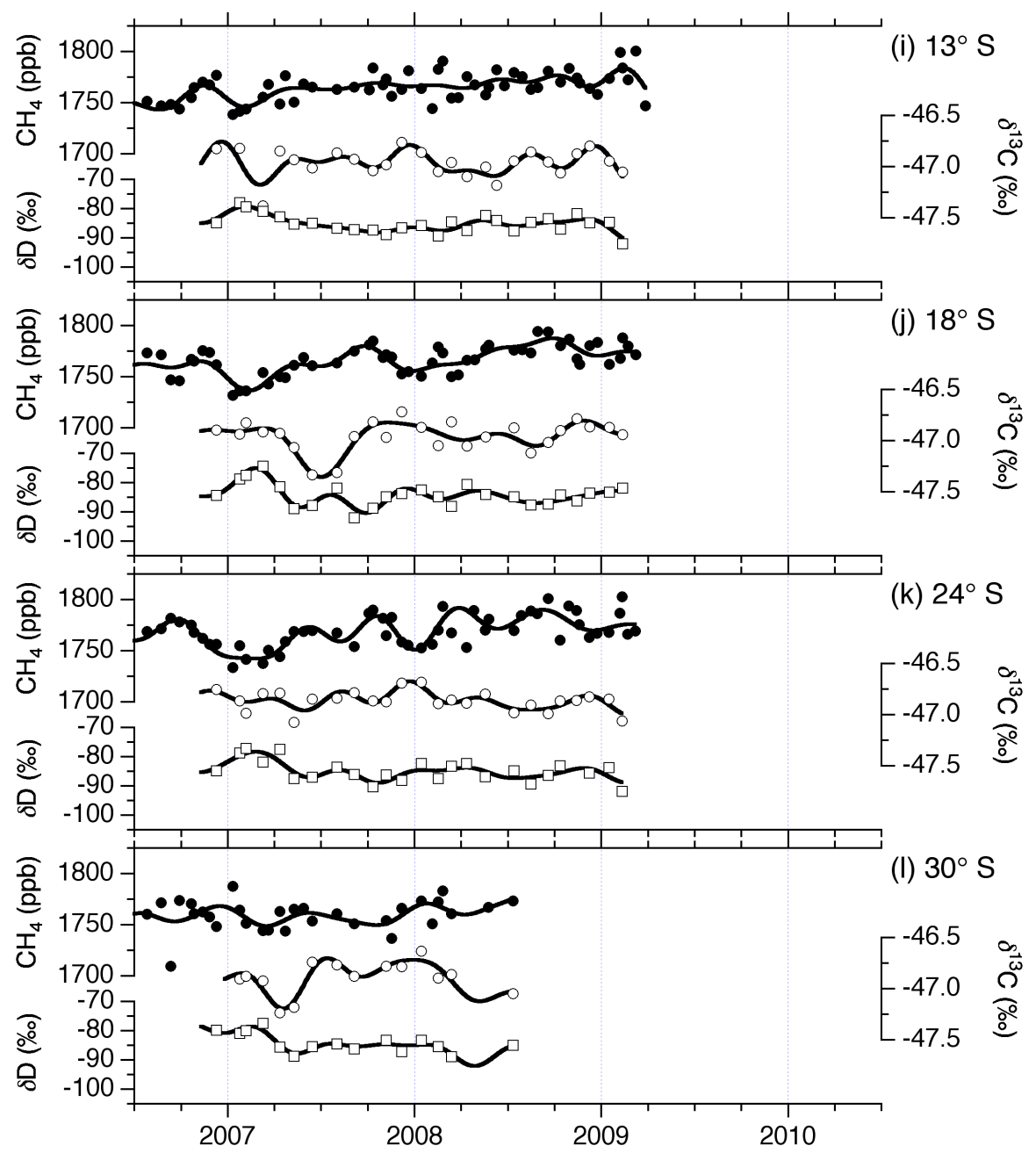

Fig. 2. Same as Fig. $2 \mathrm{a}-\mathrm{d}$, but for (i) $13^{\circ} \mathrm{S}$, (j) $18^{\circ} \mathrm{S}$, (k) $24^{\circ} \mathrm{S}$ and (l) $30^{\circ} \mathrm{S}$ beween Australia and Japan. Note that the axis ranges of the $\mathrm{CH}_{4}$ mixing ratio are different from Fig. 2a-h.

the $\mathrm{CH}_{4}$ mixing ratio for both $\delta^{13} \mathrm{C}(R=-0.45)$ and $\delta \mathrm{D}$ $(R=-0.13)$ in the southern low latitude $\left(6^{\circ} \mathrm{S}\right)$. It is seen in the $\mathrm{SH}\left(13^{\circ}-30^{\circ} \mathrm{S}\right)$ that $\delta^{13} \mathrm{C}$ and $\delta \mathrm{D}$ show negative correlations with the $\mathrm{CH}_{4}$ mixing ratio in some places, but both variables are independent of the $\mathrm{CH}_{4}$ mixing ratio as a whole. The respective correlation coefficients for $\delta^{13} \mathrm{C}$ and $\delta \mathrm{D}$ are -0.38 and -0.72 at $13^{\circ} \mathrm{S},-0.14$ and -0.48 at $18^{\circ} \mathrm{S},-0.48$ and -0.77 at $24^{\circ} \mathrm{S}$, and -0.13 and -0.46 at $30^{\circ} \mathrm{S}$.

\subsection{Comparisons of the $\mathrm{CH}_{4}$ variations in the UT with those in the LT}

To interpret variations of the $\mathrm{CH}_{4}$ mixing ratio, $\delta^{13} \mathrm{C}$ and $\delta \mathrm{D}$ in the UT, we compare them with those observed in the LT. The $\mathrm{CH}_{4}$ mixing ratio, $\delta^{13} \mathrm{C}$ and $\delta \mathrm{D}$ observed in the UT at $21^{\circ} \mathrm{N}$ are compared in Fig. 4a with those observed in the LT at $20^{\circ}-10^{\circ} \mathrm{N}$. As seen in this figure, the UT $\mathrm{CH}_{4}$ mixing ratio shows high values in boreal summer when the $\mathrm{LT} \mathrm{CH}_{4}$ shows the seasonal minimum. It is also seen in summer that the $\mathrm{CH}_{4}$ mixing ratio is often higher in the UT than in the LT. The summertime minimum $\mathrm{CH}_{4}$ mixing ratio is commonly found at surface baseline sites in northern mid-latitudes, due to a $\mathrm{CH}_{4}+\mathrm{OH}$ reaction enhanced in summer (e.g. Dlugokencky et al., 1994; Patra et al., 2009). The OH density is higher in the LT than in the UT as a whole, but its seasonal change should occur in almost the same phase throughout the troposphere (e.g. Spivakovsky et al., 2000). Therefore, the summertime high $\mathrm{CH}_{4}$ mixing ratios observed in the UT suggest an overwhelming role of transport of air masses that are strongly influenced by some $\mathrm{CH}_{4}$ sources.

The $\mathrm{CH}_{4}+\mathrm{OH}$ reaction leads to an enrichment in ${ }^{13} \mathrm{C}$ and $\mathrm{D}$ of atmospheric $\mathrm{CH}_{4}$ through the kinetic isotope effect (KIE) (e.g. Saueressig et al., 2001). As seen in Fig. 4a, $\delta^{13} \mathrm{C}$ and $\delta \mathrm{D}$ show high values in boreal summer in the NH LT, corresponding to the seasonal minimum of the $\mathrm{CH}_{4}$ mixing ratio, due to an enhanced destruction of $\mathrm{CH}_{4}$ by $\mathrm{OH}$. Similar seasonal cycles of $\delta^{13} \mathrm{C}$ and $\delta \mathrm{D}$ were observed at other 

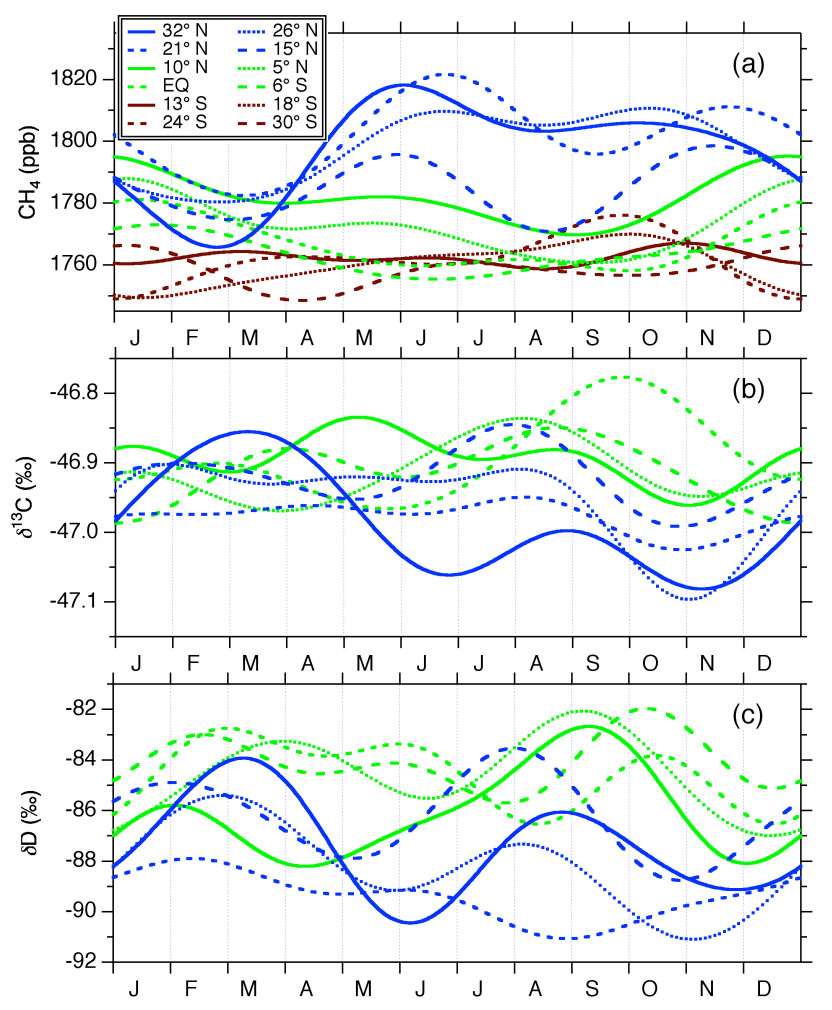

Fig. 3. Seasonal variations of (a) the $\mathrm{CH}_{4}$ mixing ratio, (b) $\delta^{13} \mathrm{C}$ and (c) $\delta \mathrm{D}$ in the NH UT over the Western Pacific. Each line represents the average seasonal cycle added by the annual average in 2007. Clear seasonal cycles of $\delta^{13} \mathrm{C}$ and $\delta \mathrm{D}$ are not observable in the $\mathrm{SH}$ and are not shown.

NH mid-latitude sites (Quay et al., 1991, 1999; Miller et al., 2002; Tyler et al., 2007). $\delta^{13} \mathrm{C}$ and $\delta \mathrm{D}$ also vary seasonally in the UT, but their phases are not always the same as those observed in the LT; in summer 2007 and $2008, \delta^{13} \mathrm{C}$ and $\delta \mathrm{D}$ show seasonal minima in the UT, but high values in the LT. Considering that the summertime $\delta^{13} \mathrm{C}$ and $\delta \mathrm{D}$ values are often lower in the UT than in the LT, $\mathrm{CH}_{4}$ sources with low $\delta^{13} \mathrm{C}$ and $\delta \mathrm{D}$ would influence the seasonal $\mathrm{CH}_{4}$ cycle in the UT.

Figure $4 \mathrm{~b}$ shows temporal variations of the $\mathrm{CH}_{4}$ mixing ratio, $\delta^{13} \mathrm{C}$ and $\delta \mathrm{D}$ in the tropical UT (the equator) and LT $\left(5^{\circ} \mathrm{N}-10^{\circ} \mathrm{S}\right)$. The UT and $\mathrm{LT} \mathrm{CH}_{4}$ mixing ratios vary almost in phase $(R=0.59)$, showing the seasonal maximum and minimum in boreal winter and summer, respectively. This would be caused by the fact that the tropical tropospheric air is vertically well mixed due to strong convection. For the seasonal $\mathrm{CH}_{4}$ cycle observed in the tropical LT, seasonally dependent air transport would be particularly important, as pointed out by Nakazawa et al. (1997a) and Yashiro et al. (2009). The intertropical convergence zone (ITCZ) in the Western Pacific migrates seasonally in association with Asian monsoon (Waliser and Gautier, 1993). Since the ITCZ is located around $10^{\circ} \mathrm{N}$ on our tracks during boreal summer, the lat-

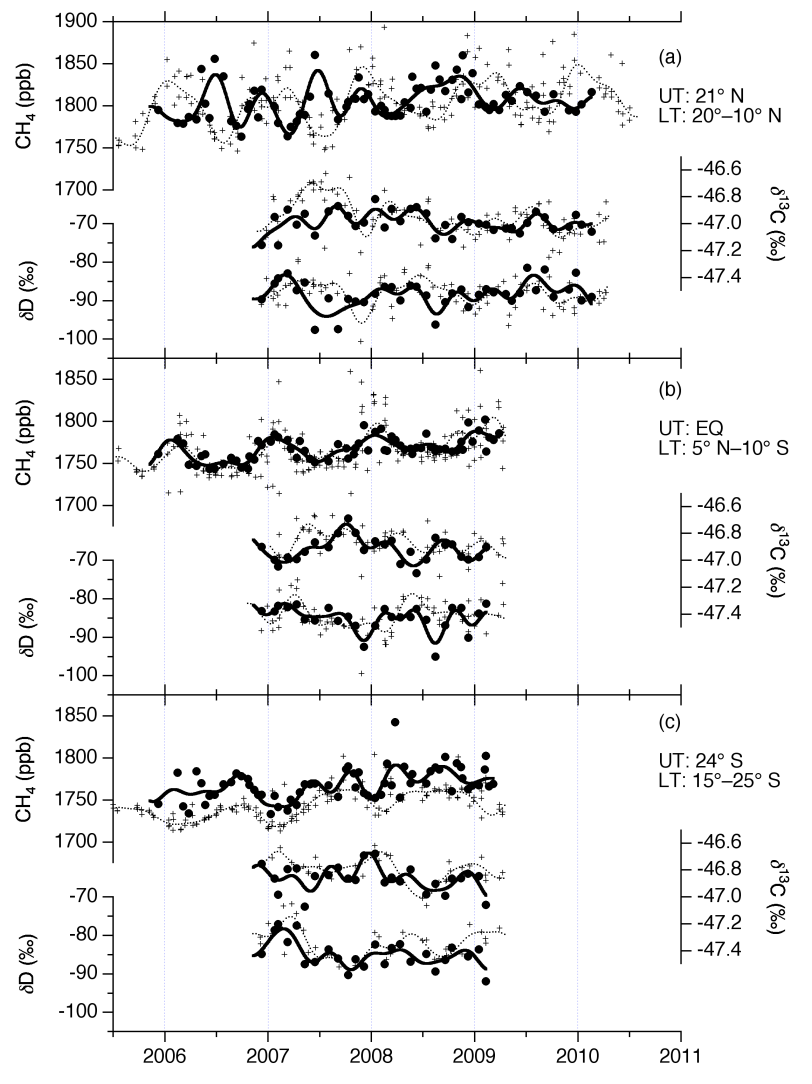

Fig. 4. Variations of the $\mathrm{CH}_{4}$ mixing ratio, $\delta^{13} \mathrm{C}$ and $\delta \mathrm{D}$ in the UT (closed circles) and LT (crosses) over the Western Pacific. Also shown are the best-fit curves to the UT (solid line) and LT (dotted line) data.

itude band $5^{\circ} \mathrm{N}-10^{\circ} \mathrm{S}$ is composed of the $\mathrm{SH}$ air with low $\mathrm{CH}_{4}$ mixing ratios. On the other hand, the ITCZ moves south of the equator in boreal winter, so that $\mathrm{NH}$ air with high $\mathrm{CH}_{4}$ mixing ratios, brought from the central Pacific by the northeast trade wind, prevails in this area.

Variations of $\delta^{13} \mathrm{C}$ and $\delta \mathrm{D}$ should also be affected by the seasonally different air transport mentioned above. In general, $\delta^{13} \mathrm{C}$ and $\delta \mathrm{D}$ are low in the NH LT, increase going southward, and are almost constant in the SH LT (Quay et al., 1999; Miller et al., 2002). Our latitudinal distributions of $\delta^{13} \mathrm{C}$ and $\delta \mathrm{D}$ in the LT, which will be presented later (Fig. 5), also show similar features. Therefore, it is expected that the transport of the $\mathrm{NH}(\mathrm{SH})$ air through the LT deplete (enrich) ${ }^{13} \mathrm{C}$ and $\mathrm{D}$ of atmospheric $\mathrm{CH}_{4}$ in the tropics. In fact, the seasonal cycles of $\delta^{13} \mathrm{C}$ and $\delta \mathrm{D}$ observed in the LT of the tropics are generally interpretable in this context (Fig. 4b).

The results observed at $24^{\circ} \mathrm{S}$ in the UT and $15^{\circ}-25^{\circ} \mathrm{S}$ in the LT are shown in Fig. 4c. As seen in this figure, the $\mathrm{SH} \mathrm{CH} 4$ mixing ratio is higher in the UT than in the LT throughout the year. Nakazawa et al. (1991) and Matsueda et al. (2002) found in the $\mathrm{SH}$ that annual-average $\mathrm{CO}_{2}$ mixing ratios are higher in the UT than in the LT, which is also shown 


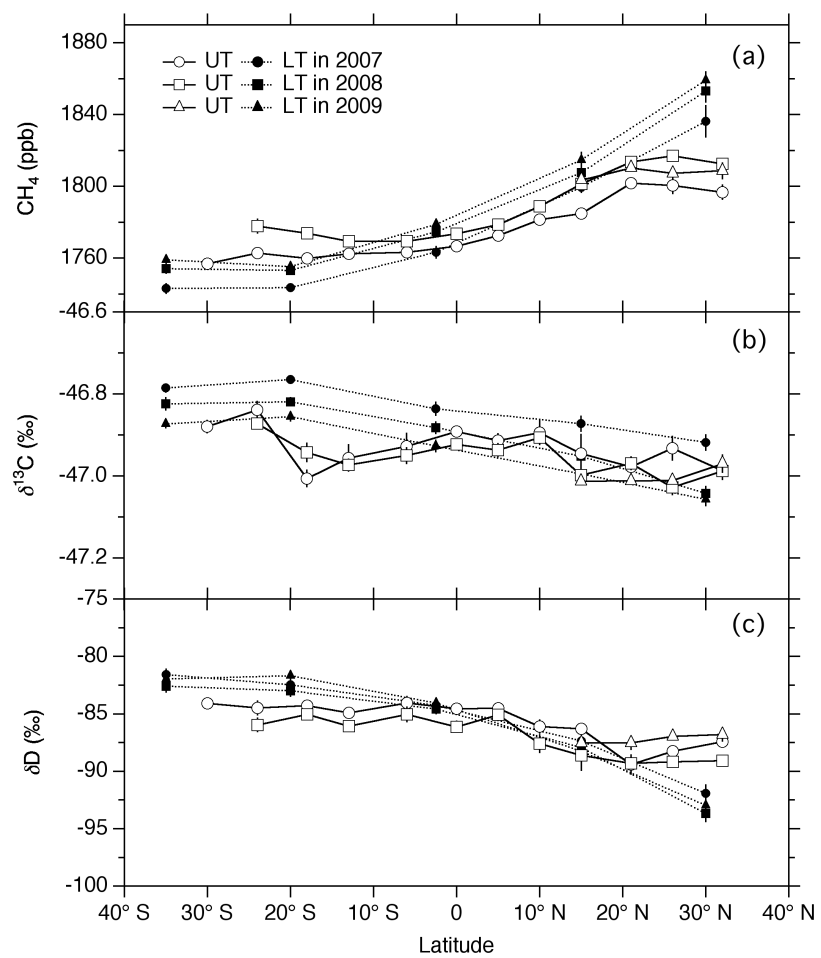

Fig. 5. Latitudinal distributions of annual averages of (a) the $\mathrm{CH}_{4}$ mixing ratio, (b) $\delta^{13} \mathrm{C}$ and (c) $\delta \mathrm{D}$ in the UT (open symbols with solid lines) and LT (closed symbols with dotted lines). Each error bar represents one standard error of the data deviations from the best-fit curves.

by a large number of in-situ $\mathrm{CO}_{2}$ data taken by CONTRAIL flights (Sawa et al., 2012). Such a $\mathrm{CO}_{2}$ increase with altitude in the $\mathrm{SH}$ is ascribed to the interhemispheric transport through the tropical UT (Miyazaki et al., 2008; Sawa et al., 2012). Similar vertical distributions of the $\mathrm{CH}_{4}$ mixing ratio were reported from aircraft measurements over Cape Grim (Francey et al., 1999). The $\mathrm{CH}_{4}$ mixing ratios obtained in this study show similar seasonal cycles in the LT and UT. In this connection, Francey et al. (1999) reported that the seasonal $\mathrm{CH}_{4}$ cycles obtained at three levels between $0-8 \mathrm{~km}$ proceed in similar phase with that at the surface. Since no strong $\mathrm{CH}_{4}$ sources exist around the Western Pacific region of the SH, the seasonal $\mathrm{CH}_{4}$ cycle could be predominantly produced by the seasonality of the $\mathrm{CH}_{4}+\mathrm{OH}$ reaction (Dlugokencky et al., 1994) as well as seasonal change of atmospheric transport of the $\mathrm{NH}$ air through the UT, as observed in the $\mathrm{CO}_{2}$ mixing ratio (Sawa et al., 2012).

The $\delta{ }^{13} \mathrm{C}$ and $\delta \mathrm{D}$ values are relatively lower in the UT than in the LT in the SH. As described earlier, air mass transport from the NH into the $\mathrm{SH}$ through the UT is responsible for this vertical difference. In this connection, the $\mathrm{NH}$ air has lower $\delta^{13} \mathrm{C}$ and $\delta \mathrm{D}$ values than the $\mathrm{SH}$ air (see Fig. 5). In order to assess the influence of $\mathrm{CH}_{4}$ sources and sinks on the observed seasonal $\mathrm{CH}_{4}$ cycle, the deviations of the isotopic ratio values from its yearly mean value are plotted against the corresponding deviations of the $\mathrm{CH}_{4}$ mixing ratio. Due to seasonal phase difference between the isotopic ratios and the $\mathrm{CH}_{4}$ mixing ratio, it is known that the plot results in an ellipse-like diagram which is called "phase ellipse" (Allan et al., 2001, 2005; Tyler et al., 2007). Allan et al. (2001, 2005) applied this analysis to the $\delta^{13} \mathrm{C}$ data obtained at Baring Head, New Zealand $\left(41^{\circ} \mathrm{S}, 175^{\circ} \mathrm{E}\right)$ and Scott Base, Antarctica $\left(78^{\circ} \mathrm{S}, 167^{\circ} \mathrm{E}\right)$ to estimate the $\mathrm{KIE}$ of the $\mathrm{CH}_{4}$ sink in the SH extratropics. They found the apparent carbon KIE of about $-13 \%$, estimated from a slope of the observed phase ellipse, being much larger than $-3.9 \%$ derived from laboratory experiments for the $\mathrm{CH}_{4}+\mathrm{OH}$ reaction (Saueressig et al., 2001). Allan et al. $(2001,2005)$ ascribed the cause to the contribution from the $\mathrm{CH}_{4}+\mathrm{Cl}$ reaction, with a large KIE of about $-60 \%$ o (Saueressig et al., 1995; Tyler et al., 2000), in the marine boundary layer. We also found a large apparent $\mathrm{KIE}$ of about $-11 \%$ o for the latitude band of $15^{\circ}-25^{\circ} \mathrm{S}$ in the LT. However, a longer data record is required to better characterize the phase ellipse, as well as to more quantitatively evaluate the contribution of the $\mathrm{CH}_{4}+\mathrm{Cl}$ reaction on the KIE. On the other hand, the impact of the $\mathrm{CH}_{4}+\mathrm{Cl}$ reaction on $\delta \mathrm{D}$ would be small, since the hydrogen KIE of this reaction is only 1.5 times larger than that of the major reaction with OH (Saueressig et al., 1996, 2001; Tyler et al., 2000).

\subsection{Latitudinal and annual changes}

\subsubsection{Latitudinal distribution in the UT and LT}

Figure 5 shows the latitudinal distributions of annual averages of the $\mathrm{CH}_{4}$ mixing ratio, $\delta^{13} \mathrm{C}$ and $\delta \mathrm{D}$ in the UT and LT for the period 2007-2009. The UT distributions for 20072008 and 2009 were derived from the data taken between NRT and SYD or BNE and between NRT and GUM, respectively. In the LT, the $\mathrm{CH}_{4}$ mixing ratio is high in the $\mathrm{NH}$ and decreases going southward until the value is almost constant in the extratropical SH. The $\mathrm{CH}_{4}$ mixing ratio in the northernmost latitude band is about $100 \mathrm{ppb}$ higher than the value in the extratropical SH. Such a latitudinal distribution of the $\mathrm{CH}_{4}$ mixing ratio has been reported from the global baseline network (Dlugokencky et al., 1994), attributing the cause to the fact that a large portion of $\mathrm{CH}_{4}$ source is located in the $\mathrm{NH}$ (e.g. Fung et al., 1991). The UT $\mathrm{CH}_{4}$ mixing ratio is higher in the $\mathrm{NH}$ than in the $\mathrm{SH}$, but the north-south gradient in the UT (about $45 \mathrm{ppb}$ ) is smaller than that in the LT. It is also seen from Fig. 5 that the latitudinal distributions of the $\mathrm{CH}_{4}$ mixing ratio in the UT and LT cross each other in the tropics; the $\mathrm{CH}_{4}$ mixing ratio is lower in the UT than in the LT in the NH, and vice versa in the SH. Such latitudinal distributions are due to $\mathrm{CH}_{4}$ emissions from the $\mathrm{NH}$ surface as well as to the intrusion of $\mathrm{NH}$ air into the $\mathrm{SH}$ through the UT. A similar distribution feature has been reported for the $\mathrm{CO}_{2}$ mixing ratio from measurements on the same flight 
route as this study (Nakazawa et al., 1991; Matsueda et al., 2002), more frequent and wider coverage measurements of the CONTRAIL project (Sawa et al., 2012) and global-scale simulations (Miyazaki et al., 2008).

In the $\mathrm{LT}, \delta^{13} \mathrm{C}$ increases with decreasing latitude from the $\mathrm{NH}$ to the tropics and the values are almost constant in the extratropical SH. A similar distribution has been reported from surface and shipboard measurements (Quay et al., 1991, 1999; Miller et al., 2002). The observed north-south gradient of $\delta^{13} \mathrm{C}$ arises from the process that a large amount of $\mathrm{CH}_{4}$ is emitted in the $\mathrm{NH}$ from biogenic sources with low $\delta^{13} \mathrm{C}$ such as wetlands, rice paddies and ruminant animals and ${ }^{13} \mathrm{C}$ of atmospheric $\mathrm{CH}_{4}$ is enriched by the $\mathrm{OH}$ reaction during southward transport (Miller et al., 2002). The north-south gradient of $\delta^{13} \mathrm{C}$ is also found in the UT, but it is less pronounced than that in the LT. Compared with $\delta^{13} \mathrm{C}$ in the LT, the UT value is almost equal in the $\mathrm{NH}$ and the tropics and lower in the $\mathrm{SH}$. As a result, $\delta^{13} \mathrm{C}$ does not show any clear intersection of the latitudinal distributions in the LT and UT.

In the LT, $\delta \mathrm{D}$ shows almost the same latitudinal distributions as $\delta^{13} \mathrm{C}$. The latitudinal distribution of $\delta \mathrm{D}$ was also measured by Quay et al. (1999) and Rice et al. (2001) using ships in the Eastern Pacific, but their measurements are not systematic. The north-south gradient of $\delta \mathrm{D}$ in the LT can be interpreted in terms of unevenly distributed $\mathrm{CH}_{4}$ sources in the $\mathrm{NH}$ and the $\mathrm{SH}$, as well as the $\mathrm{KIE}$ by the $\mathrm{OH}$ reaction. The north-south gradient of $\delta \mathrm{D}$ is also apparent in the UT, although it is less pronounced than in the LT. Compared with $\delta \mathrm{D}$ in the LT, the UT value is lower and higher in the NH and the $\mathrm{SH}$, respectively, yielding a intersection of the UT and LT latitudinal $\delta \mathrm{D}$ distributions, as was found in the $\mathrm{CH}_{4}$ mixing ratio. A possible cause of the intersection is ascribed to the intrusion of $\mathrm{NH}$ air into the $\mathrm{SH}$ through the UT.

As described above, the $\mathrm{CH}_{4}$ mixing ratio and $\delta \mathrm{D}$ show the LT and UT latitudinal profiles crossing each other in the tropics, while such a crossing is not seen for $\delta^{13} \mathrm{C}$. To interpret the observed $\delta^{13} \mathrm{C}$ latitudinal profiles, some mechanism should be considered, in addition to the $\mathrm{NH}$ air intrusion, by which $\delta^{13} \mathrm{C}$ is increased in the LT or decreased in the UT with no significant impact on the $\mathrm{CH}_{4}$ mixing ratio and $\delta \mathrm{D}$. A possible explanation is ascribed to the $\mathrm{CH}_{4}+\mathrm{Cl}$ reaction, which enriches ${ }^{13} \mathrm{C}$ significantly by its large KIE of about $-60 \%$ (Saueressig et al., 1995; Tyler et al., 2000) in the marine boundary layer (e.g. Allan et al., 2007). Since the present observations in the LT were made just above the open sea in the Western Pacific, our $\delta^{13} \mathrm{C}$ values in the LT could have been enriched significantly by the $\mathrm{Cl}$ reaction over all observation latitudes. If the $\delta^{13} \mathrm{C}$ values in the LT were lowered by about $0.05 \%$, the resultant latitudinal profile would have intersected the UT profile in the tropics. Given that our LT ${ }^{13} \mathrm{C}$ values are increased by this amount due to the $\mathrm{Cl}$ reaction with a large KIE, the contribution of the reaction to the $\mathrm{CH}_{4}$ mixing ratio is estimated to be only $2 \mathrm{ppb}$ (see also formulae by Allan et al., 2001). Such a small contribution could merge into data variability of the $\mathrm{CH}_{4}$ mixing ratio. As men- tioned earlier, impact of the $\mathrm{CH}_{4}+\mathrm{Cl}$ reaction on $\delta \mathrm{D}$ is also expected to be small due to a relatively small difference of the hydrogen KIE between the $\mathrm{Cl}$ and $\mathrm{OH}$ reactions.

\subsubsection{Recent increase of atmospheric $\mathrm{CH}_{4}$}

As seen in Fig. 5, the average $\mathrm{CH}_{4}$ mixing ratio is increased by about $10 \mathrm{ppb}$ at $30^{\circ}-40^{\circ} \mathrm{S}, 15^{\circ}-25^{\circ} \mathrm{S}, 5^{\circ} \mathrm{N}-10^{\circ} \mathrm{S}$ and $20^{\circ}-10^{\circ} \mathrm{N}$ and by $17 \mathrm{ppb}$ at $35^{\circ}-25^{\circ} \mathrm{N}$ in the LT from 2007 to 2008. The mixing ratio increase between 2008 and 2009 is about $5 \mathrm{ppb}$ for all latitude bands. Such a mixing ratio increase is consistent with the results from baseline measurements (Dlugokencky et al., 2009; Terao et al., 2011). On the other hand, the respective decreases in $\delta^{13} \mathrm{C}$ and $\delta \mathrm{D}$ between 2007 and 2008 are about $0.05 \%$ and $0.6 \%$ in the SH and the tropics $\left(30^{\circ}-40^{\circ} \mathrm{S}\right.$ to $\left.5^{\circ} \mathrm{N}-10^{\circ} \mathrm{S}\right)$ and by about $0.10 \%$ 。 and $1.2 \% \circ$ at $\mathrm{NH}$ mid-latitudes $\left(20^{\circ}-10^{\circ} \mathrm{N}\right.$ and $\left.35^{\circ}-25^{\circ} \mathrm{N}\right)$, showing slightly more prominent decreases in the $\mathrm{NH}$ than in the tropics and $\mathrm{SH}$. Such temporal decreases in $\delta^{13} \mathrm{C}$ and $\delta \mathrm{D}$ suggest that the $\mathrm{CH}_{4}$ mixing ratio increase was caused by enhanced emissions of isotopically light $\mathrm{CH}_{4}$ from biogenic sources such as wetlands and rice paddies. For the period 2008-2009, no significant temporal change in $\delta^{13} \mathrm{C}$ $(<0.04 \% o)$ and $\delta \mathrm{D}(<1 \%$ ) were observed at all latitudes in the LT covered by this study. The $\mathrm{CH}_{4}$ mixing ratio in the UT increased by about $7 \mathrm{ppb}$ in the tropics $\left(13^{\circ} \mathrm{S}-10^{\circ} \mathrm{N}\right)$ and by about $15 \mathrm{ppb}$ in the extratropics of both hemispheres between 2007 and 2008. On the other hand, $\delta^{13} \mathrm{C}$ and $\delta \mathrm{D}$ showed similar values in the two years at all latitudes, the differences for the respective variables being -0.03 and $-1.2 \%$.

Rigby et al. (2008) and Sasakawa et al. (2010) found high temperature anomalies in Siberia in 2007, suggesting that $\mathrm{CH}_{4}$ emissions from boreal wetlands were enhanced. By using a two-dimensional box model with possible changes in $\mathrm{OH}$, Rigby et al. (2008) indicated that the $\mathrm{CH}_{4}$ increase in 2007 is attributable to $\mathrm{CH}_{4}$ emissions enhanced in the $\mathrm{NH}$. Dlugokencky et al. (2009) also suggested an enhancement of $\mathrm{CH}_{4}$ emissions from boreal wetlands, resulting in the largest $\mathrm{CH}_{4}$ increase in the Arctic and low $\delta^{13} \mathrm{C}$ values at northern high-latitude site Alert, Canada, in late summer of 2007. On the other hand, Bousquet et al. (2011) indicated from their atmospheric inversion modeling that tropical wetlands are a dominant contributor to the $\mathrm{CH}_{4}$ increase in 2007, also with a significant but smaller contribution from boreal wetlands. These earlier studies support our observational results that $\delta^{13} \mathrm{C}$ and $\delta \mathrm{D}$ decreased in the LT of the NH in 20072008. In addition, the $\mathrm{CH}_{4}$ increase in the whole troposphere observed in this study might be explained by tropical $\mathrm{CH}_{4}$ emissions combined with rapid vertical transport (Houweling et al., 2006; Bousquet et al., 2011), although insignificant changes in $\delta^{13} \mathrm{C}$ and $\delta \mathrm{D}$ do not allow us to identify the source type. 


\subsection{Summertime elevated $\mathrm{CH}_{4}$ in the UT of the $\mathrm{NH}$}

\subsubsection{Tagged tracer results}

To examine causes of the high $\mathrm{CH}_{4}$ mixing ratios observed in the NH UT in summer, we made tagged tracer experiments using the ACTM. Figure 6 shows the comparison of the observed and model-simulated $\mathrm{CH}_{4}$ mixing ratios for the UT at $32^{\circ}-15^{\circ} \mathrm{N}$. As seen in this figure, the model reproduces the observed variations relatively well, especially for the timing of high $\mathrm{CH}_{4}$ mixing ratios. The tagged tracers for the respective regions are also shown in Fig. 6. As clearly seen in this figure, Region 5 (South Asia) and Region 6 (East Asia) play an important role in the $\mathrm{CH}_{4}$ variations in the NH UT (see Table 1 and Fig. 1). The contribution of South Asia is larger than that of East Asia as a whole, and both regions are closely related to the high $\mathrm{CH}_{4}$ mixing ratios in boreal summer-autumn, $\mathrm{CH}_{4}$ from South Asia and East Asia being important for September-October and MaySeptember, respectively. Such high $\mathrm{CH}_{4}$ mixing ratios would be due to rapid upward transport of the boundary layer air by Asian summer monsoon (Jiang et al., 2007; Park et al., 2009; Xiong et al., 2009; Schuck et al., 2010). A sensitivity test, in which the model was run with and without seasonally varying sources, also indicates that enhanced vertical transport over these two regions predominantly drives the summertime high $\mathrm{CH}_{4}$ mixing ratio peaks in the UT. It should be also noted that the $\mathrm{CH}_{4}$ emission from rice paddies used in the model reaches a maximum around August-September in South Asia and June in East Asia.

It is also found from Fig. 6 that the differences between the observed and simulated $\mathrm{CH}_{4}$ mixing ratios become larger after 2008. Since our model reproduces the timing of the observed $\mathrm{CH}_{4}$ peaks relatively well, the meteorological field and $\mathrm{CH}_{4}$ source distributions can be plausibly incorporated into the model. Therefore, the large differences between the simulated and observed $\mathrm{CH}_{4}$ mixing ratios after 2008 could be caused by underestimated $\mathrm{CH}_{4}$ emissions in the model.

\subsubsection{Isotopic signatures of $\mathrm{CH}_{4}$ sources in South Asia and East Asia}

Figure 7 shows plots of $\delta^{13} \mathrm{C}$ and $\delta \mathrm{D}$ against the reciprocal of the $\mathrm{CH}_{4}$ mixing ratio for the UT at $15^{\circ}-32^{\circ} \mathrm{N}$. This kind of plot is called as Keeling plot and often used to estimate the isotopic ratio of a source that exchanges a trace gas with the atmosphere (e.g. Pataki et al., 2003). In the light of the results of the tagged tracer experiments, we categorized the observed data into three regions of South Asia, East Asia and the rest of the world (hereafter referred to as baseline). The air samples categorized into the two regions have extremely high values of the corresponding tagged tracers for the respective regions, which exceed the average plus one standard deviation calculated for the observation period. The South Asian and East Asian samples were found in May-October with only one exception (December). It is obvious from Fig. 7 that air originating in South Asia and East Asia has higher $\mathrm{CH}_{4}$ mixing ratios and lower $\delta^{13} \mathrm{C}$ and $\delta \mathrm{D}$ than those of the baseline air. The average $\mathrm{CH}_{4}$ mixing ratios are $(1819 \pm 28)$ and $(1827 \pm 26)$ ppb for the SouthAsian and East-Asian air, respectively, while the mixing ratio value of the baseline air is $(1796 \pm 22) \mathrm{ppb}$, and the respective average values of $\delta^{13} \mathrm{C}$ and $\delta \mathrm{D}$ are $(-47.08 \pm 0.11)$ and $(-90.3 \pm 4.1) \%$ for South Asia and $(-47.01 \pm 0.11)$ and $(-90.5 \pm 3.9) \%$ o for East Asia, while the corresponding values are $(-46.96 \pm 0.11)$ and $(-87.3 \pm 3.6) \%$ for the baseline air. Although the differences of the $\mathrm{CH}_{4}$ mixing ratio and isotopic ratios between the South Asian or East Asian air and the baseline air are small, we attempt the following analysis with these values.

If it is assumed that $\mathrm{CH}_{4}$ is emitted into the atmosphere from a single $\mathrm{CH}_{4}$ source, the isotopic ratio of that source can be inferred as an end-member for the baseline on a Keeling plot (e.g. Bergamaschi et al., 1998). Using our data, we found the respective end-member signatures of $\delta^{13} \mathrm{C}$ and $\delta \mathrm{D}$ relative to the baseline to be $-56.5 \%$ and $-329 \%$ or South Asia, and $-49.6 \%$ and $-277 \%$ or East Asia. Although the obtained isotopic ratios include very large uncertainties, due to small differences of the $\mathrm{CH}_{4}$ mixing ratio and isotopic ratios between South Asian and East Asian air and the baseline air, these values suggest a mix of source with substantial contributions from ${ }^{13} \mathrm{C}$ and $\mathrm{D}$ depleted sources such as biogenic emissions from rice paddies and livestock. The model $\mathrm{CH}_{4}$ flux indicates that $\mathrm{CH}_{4}$ emissions from rice paddies are enhanced in summer in both regions, which is generally consistent with the isotopic signatures estimated in this study. The above assumption is usually valid for the atmosphere close to the source, such as in the forest canopy (e.g. Pataki et al., 2003) and the boundary layer (e.g. Llyod et al., 2001; Umezawa et al., 2011), but our measurements were made in the UT. Therefore, it should be noted that the sampled air would be influenced not only by $\mathrm{CH}_{4}$ sources but also by chemical destruction and mixing during transport.

\subsection{Longitudinal variations in the UT of the NH}

Figure 8 shows longitudinal distributions of the $\mathrm{CH}_{4}$ mixing ratio, $\delta{ }^{13} \mathrm{C}$ and $\delta \mathrm{D}$ in the UT between NRT and HNL. As seen in this figure, the $\mathrm{CH}_{4}$ mixing ratios observed in May 2010 are extremely low between $160^{\circ}-180^{\circ} \mathrm{E}$, with the minimum value of $1655 \mathrm{ppb}$ around $170^{\circ} \mathrm{E}$. Such low $\mathrm{CH}_{4}$ mixing ratios were not observed in the UT between NRT and SYD or BNE or between NRT and GUM (Fig. 2). The air samples with low $\mathrm{CH}_{4}$ mixing ratios show high values of $\delta^{13} \mathrm{C}$ and $\delta \mathrm{D}$. To examine the cause, we analyzed the Japan Meteorological Agency Climate Data Assimilation System (JCDAS) reanalysis data (Onogi et al., 2007), following the same method as used in Sawa et al. (2008), in which potential vorticity (PV) in PV-units (PVU $=10^{-6} \mathrm{Km}^{2} \mathrm{~kg}^{-1} \mathrm{~s}^{-1}$ ) was adopted as a measure of stratospheric air. By inspecting the 

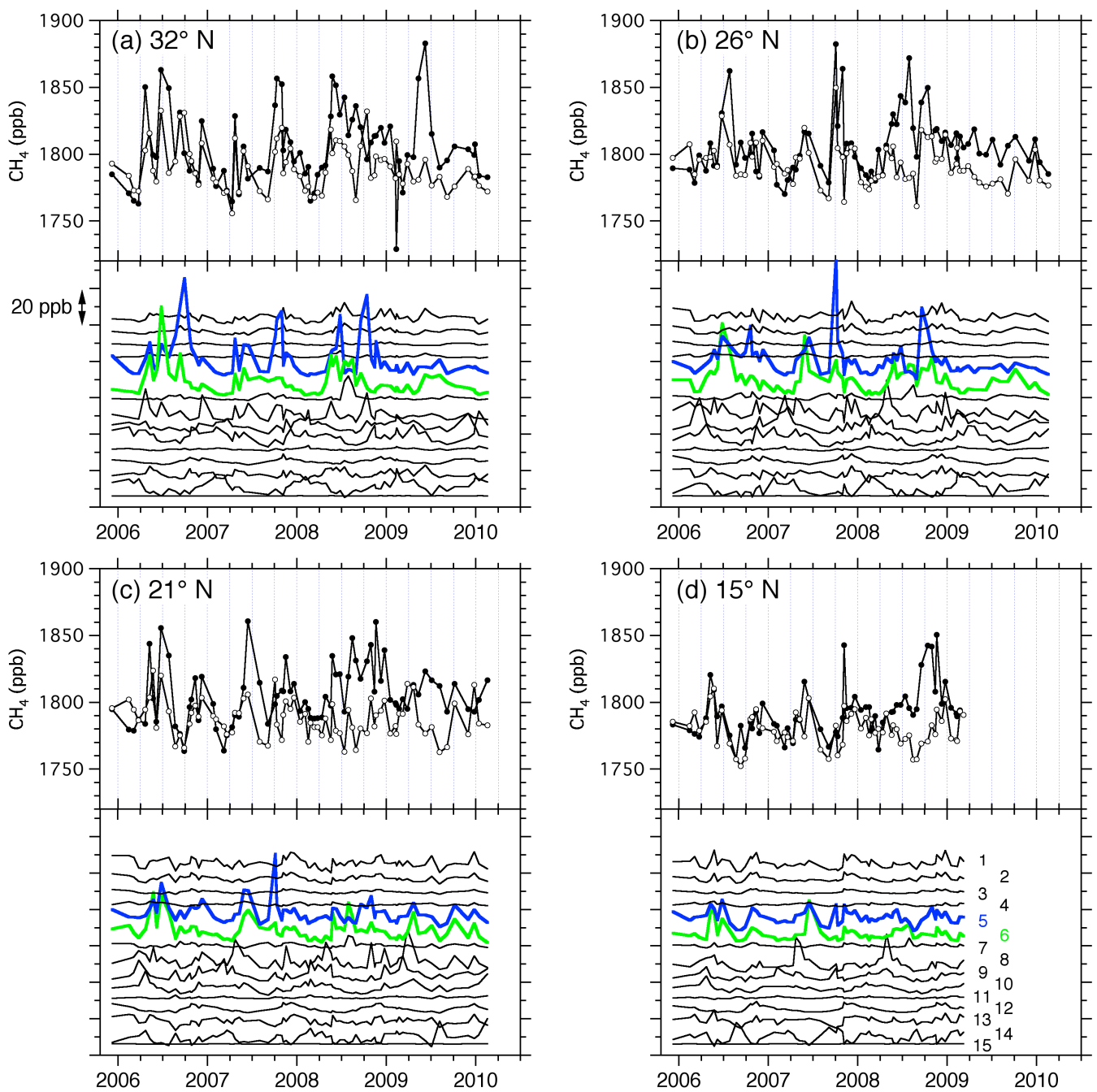

Fig. 6. Comparison of the observed (closed circles) and model-simulated (open circles) $\mathrm{CH}_{4}$ mixing ratios for the UT at (a) $32^{\circ} \mathrm{N}$. (b) $26^{\circ} \mathrm{N}$, (c) $21^{\circ} \mathrm{N}$ and (d) $15^{\circ} \mathrm{N}$. In each lower panel the tagged tracers for the respective regions 1-15 (from top to bottom) are shown. Blue and green lines represent Region 5 (South Asia) and Region 6 (East Asia), respectively, and each line is offset for easy view.

PV distribution along the flight route, we found that stratospheric air ( $>3 \mathrm{PVU}$ ) intruded into the UT around $160^{\circ}-$ $180^{\circ} \mathrm{E}$. It is known that the $\mathrm{CH}_{4}$ mixing ratio decreases rapidly with increasing altitude in the stratosphere (e.g. Sugawara et al., 1997). In the stratosphere, no $\mathrm{CH}_{4}$ sources exist and $\mathrm{CH}_{4}$ is destroyed by chemical reactions with $\mathrm{OH}, \mathrm{Cl}$ and $\mathrm{O}\left({ }^{1} \mathrm{D}\right)$. Therefore, $\mathrm{CH}_{4}$ is enriched in ${ }^{13} \mathrm{C}$ and $\mathrm{D}$ by the KIEs due to these reactions during its long residence time in the stratosphere (Sugawara et al., 1997; Rice et al., 2003; Röckmann et al., 2011). Regarding the air samples collected around $160^{\circ}-180^{\circ} \mathrm{E}$, the $\mathrm{N}_{2} \mathrm{O}$ mixing ratios in the corresponding air samples were also lower than those of the other samples, due to the influence of stratospheric air.

Another interesting feature is that relatively high $\mathrm{CH}_{4}$ mixing ratios, accompanied by low $\delta^{13} \mathrm{C}$ and $\delta \mathrm{D}$ values, were observed in September 2010. As mentioned above, the ob- servations in the NH UT between NRT and SYD or BNE and between NRT and GUM indicate that the $\mathrm{CH}_{4}$ mixing ratio is high in this season (Fig. 2a-d), due to $\mathrm{CH}_{4}$ from South Asia and East Asia. Observed longitudinal distributions showed the eastward decrease of the $\mathrm{CH}_{4}$ mixing ratio and increase of $\delta^{13} \mathrm{C}$ and $\delta \mathrm{D}$ in the east of the $\mathrm{CH}_{4}$ maximum at $170^{\circ} \mathrm{E}$, probably due to $\mathrm{CH}_{4}$ outflow from South Asia and East Asia.

\section{Conclusions}

To elucidate temporal and spatial variations of the $\mathrm{CH}_{4}$ mixing ratio, $\delta{ }^{13} \mathrm{C}$ and $\delta \mathrm{D}$ in the UT over the Western Pacific, air samples collected using the CONTAIL were analyzed. In the $\mathrm{NH}$, the $\mathrm{CH}_{4}$ mixing ratio showed high values in boreal summer, accompanied by relatively low $\delta^{13} \mathrm{C}$ and $\delta \mathrm{D}$ values. By comparing with the LT data obtained using container ships 


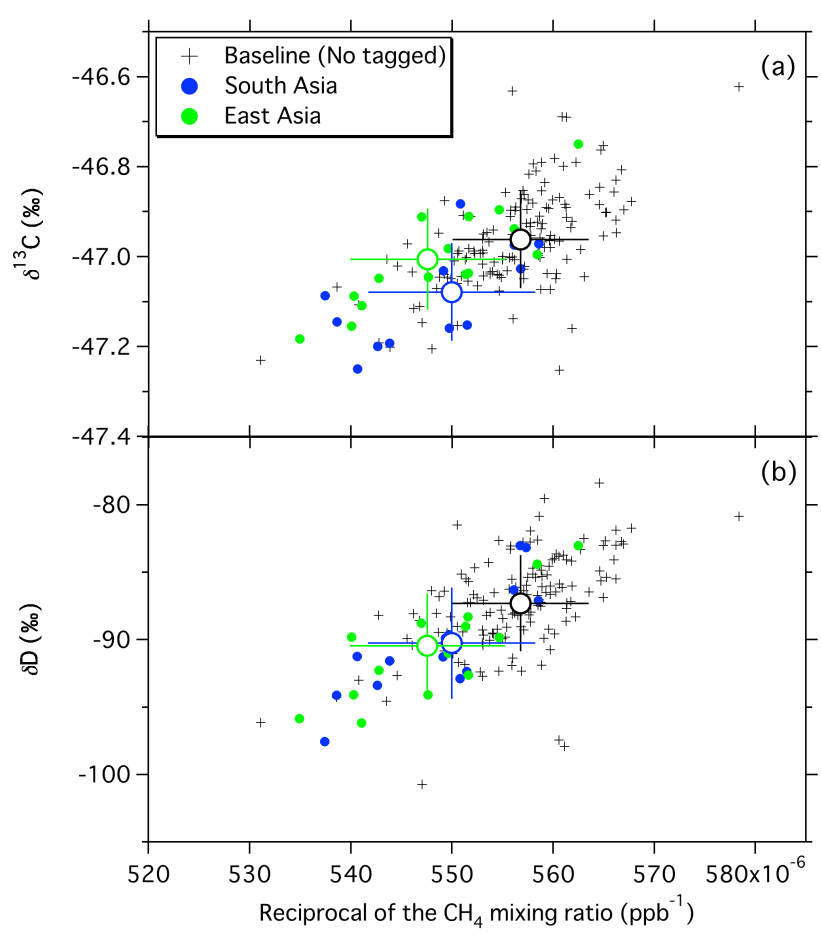

Fig. 7. Plots for (a) $\delta^{13} \mathrm{C}$ and (b) $\delta \mathrm{D}$ relative to the reciprocal of the $\mathrm{CH}_{4}$ mixing ratio for the UT at $15^{\circ}-32^{\circ} \mathrm{N}$. All data plotted were categorized as "Baseline" (black crosses), "South Asia" (blue closed circles) or "East Asia" (green closed circles) based on the tagged tracer experiments. Also shown are the average values of the data for the respective categories (open circles).

in the same region, it was found in the $\mathrm{NH}$ that $\mathrm{CH}_{4}$ mixing ratios were higher in the UT than in the LT in summer. From the tagged tracer experiments, we found that $\mathrm{CH}_{4}$ sources in South Asia and East Asia play an important role in the summertime high $\mathrm{CH}_{4}$ mixing ratio values in the NH UT. The observed data of $\delta^{13} \mathrm{C}$ and $\delta \mathrm{D}$ also indicated potential contributions of isotopically depleted biogenic $\mathrm{CH}_{4}$ sources such as rice paddies and livestock to the high $\mathrm{CH}_{4}$ mixing ratios observed in the NH UT.

The latitudinal distributions of the $\mathrm{CH}_{4}$ mixing ratio and $\delta \mathrm{D}$ in the LT and UT were found to intersect at low latitudes; the $\mathrm{CH}_{4}$ mixing ratio and $\delta \mathrm{D}$ were higher and lower, respectively, in the LT than in the UT in the NH, and the situation is reversed in the $\mathrm{SH}$. On the other hand, $\delta^{13} \mathrm{C}$ showed similar values in the LT and UT of the $\mathrm{NH}$, but the value is higher in the LT than in the UT in the SH. These latitudinal distributions can be interpreted mainly in terms of the $\mathrm{NH}$ air intrusion into the $\mathrm{SH}$ through the UT, but the $\mathrm{CH}_{4}+\mathrm{Cl}$ reaction in the marine boundary layer may also affect the $\delta^{13} \mathrm{C}$ distributions to some extent. Our data also indicate that the $\mathrm{CH}_{4}$ mixing ratio has increased again since 2007 , due to emissions of isotopically light biogenic $\mathrm{CH}_{4}$ in the tropics and northern latitudes.

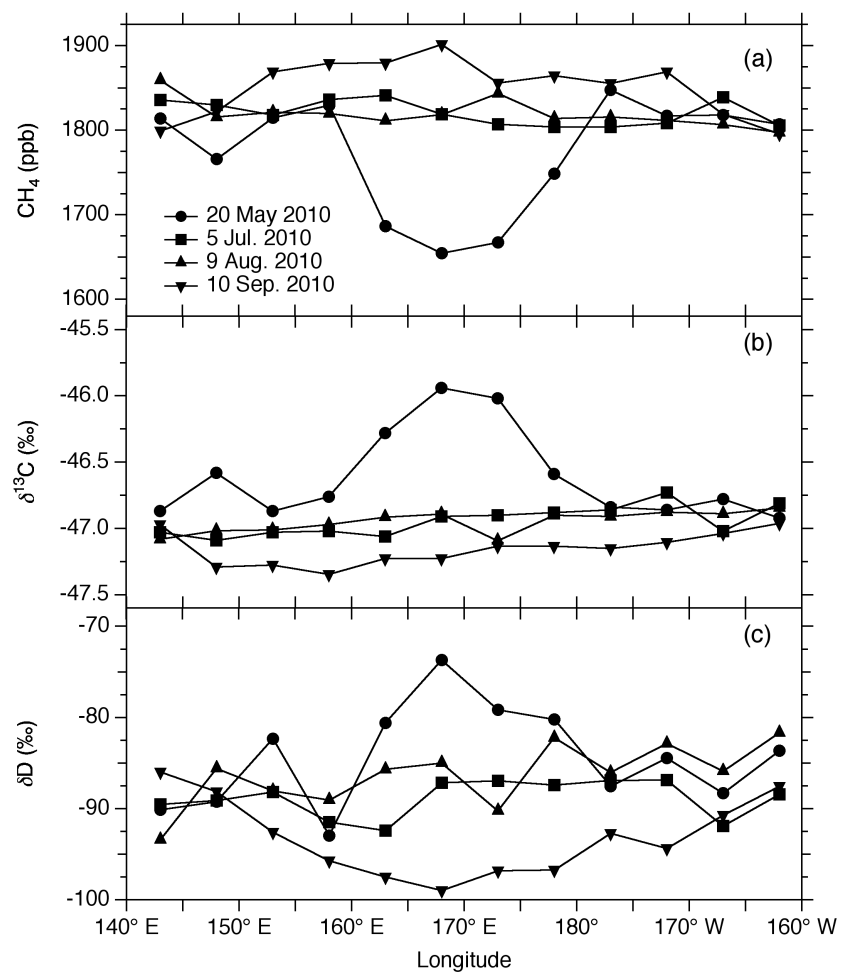

Fig. 8. Longitudinal distributions of (a) the $\mathrm{CH}_{4}$ mixing ratio, (b) $\delta^{13} \mathrm{C}$ and (c) $\delta \mathrm{D}$ observed in four flights between Honolulu, Hawaii and Narita, Japan.

The analyses of $\delta^{13} \mathrm{C}$ and $\delta \mathrm{D}$ in combination with the $\mathrm{CH}_{4}$ mixing ratio are very useful for a better understanding of the global $\mathrm{CH}_{4}$ cycle. However, systematic measurements are still quite sparse. To examine their spatiotemporal variations in more detail, long-term measurements of these variables over a geographically wide area are required. In addition to conventional analyses on IRMS, it is also expected that high-frequency isotopic data will be obtained using quantum laser spectroscopy in the near future (e.g. Rigby et al., 2012). Modeling studies based on $\delta^{13} \mathrm{C}$ and $\delta \mathrm{D}$ as well as the $\mathrm{CH}_{4}$ mixing ratio are also necessary for quantitatively elucidating the $\mathrm{CH}_{4}$ cycle, as well as for estimating the $\mathrm{CH}_{4}$ budget.

\section{Supplementary material related to this article is available online at: http://www.atmos-chem-phys.net/12/ 8095/2012/acp-12-8095-2012-supplement.zip.}

Acknowledgements. We are grateful to Japan Airlines (JAL), JAL foundation and JAMCO for supporting the CONTRAIL project. We also appreciate Hachiuma Steamship CO. Ltd., NYK Line, NYK shipmanagement Pte. Ltd., and staffs of container ships for their cooperation in collecting air samples. Our thanks are due to K. Katsumata and H. Sandanbata, NIES and F. Arai and 
J. Miyakozawa, Tohoku University for their $\mathrm{CH}_{4}$ mixing ratio analyses. We also thank two anonymous referees and A. Baker for their comments to improve this paper.

Edited by: J. Kaiser

\section{References}

Allan, W., Manning, M. R., Lassey, K. R., Lowe, D. C., and Gomez, A. J.: Modeling the variation of $\delta^{13} \mathrm{C}$ in atmospheric methane: Phase ellipses and the kinetic isotope effect, Global Biogeochem. Cy., 15, 467-481, 2001.

Allan, W., Lowe, D. C., Gomez, A. J., Struthers, H., and Brailsford, G. W.: Interannual variation of ${ }^{13} \mathrm{C}$ in tropospheric methane: Implications for a possible atomic chlorine sink in the marine boundary layer, J. Geophys. Res., 110, D11306, doi:10.1029/2004JD005650, 2005.

Allan, W., Struthers, H., and Lowe, D. C.: Methane carbon isotope effects caused by atomic chlorine in the marine boundary layer: Global model results compared with Southern Hemisphere measurements, J. Geophys. Res., 112, D04306, doi:10.1029/2006JD007369, 2007.

Aoki, S., Nakazawa, T., Murayama, S. and Kawaguchi, S.: Measurements of atmospheric methane at the Japanese Antarctic Station. Syowa, Tellus, 44B, 273-281, 1992.

Baker, A. K., Schuck, T. J., Slemr, F., van Velthoven, P., Zahn, A., and Brenninkmeijer, C. A. M.: Characterization of nonmethane hydrocarbons in Asian summer monsoon outflow observed by the CARIBIC aircraft, Atmos. Chem. Phys., 11, 503518, doi:10.5194/acp-11-503-2011, 2011.

Bergamaschi, P., Brenninkmeijer, C. A. M., Hahn, M., Röckmann, T., Scharffe, D. H., Crutzen, P. J., Elansky, N. F., Belikov, I. B., Trivett, N. B. A. and Worthy, D. E. J.: Isotope analysis based source identification for atmospheric $\mathrm{CH}_{4}$ and $\mathrm{CO}$ sampled across Russia using the Trans-Siberian railroad, J. Geophys. Res., 103, 8227-8235, 1998.

Bergamaschi, P., Frankenberg, C., Meirink, J. F., Krol, M., Dentener, F., Wagner, T., Platt, U., Kaplan, J. O., Körner, S., Heimann, M., Dlugokencky, E. J., and Goede, A.: Satellite chartography of atmospheric methane from SCIAMACHY on board ENVISAT: 2. Evaluation based on inverse model simulations, J. Geophys. Res., 112, D2304, doi:10.1029/2006JD007268, 2007.

Bergamaschi, P., Frankenberg, C., Meirink, J. F., Krol, M., Villani, M. G., Houweling, S., Dentener, F., Dlugokencky, E. J., Miller, J. B., Gatti, L. V., Engel, A. and Levin, I.: Inverse modeling of global and regional $\mathrm{CH}_{4}$ emissions using SCIAMACHY satellite retrievals, J. Geophys. Res., 114, D22301, doi:10.1029/2009JD012287, 2009.

Bhattacharya, S. K., Borole, D. V., Francey, R. J., Allison, C. E., Steele, L. P., Krummel, P., Langenfelds, R., Masarie, K. A., Tiwari, Y. K., and Patra, P. K.: Trace gases and $\mathrm{CO}_{2}$ isotope records from Cabo de Rama, India, Curr. Sci., 97, 1336-1344, 2009.

Blake, D. R. and Rowland, F. S.: World-wide increase in tropospheric methane, 1978-1983, J. Atmos. Chem., 4, 43-62, 1986.

Bock, M., Schmitt, J., Behrens, M., Möller, L., Schneider, R., Sapart, C., and Fischer, H.: A gas chromatography/pyrolysis/isotope ratio mass spectrometry system for highprecision $\delta \mathrm{D}$ measurements of atmospheric methane extracted from ice cores, Rapid Commun. Mass Spectrom., 24, 621-633, 2010.

Bousquet, P., Ciais, P., Miller, J. B., Dlugokencky, E. J., Hauglustaine, D. A., Prigent, C., Van der Werf, G. R., Peylin, P., Brunke, E.-G., Carouge, C., Langenfelds, R. L., Lathière, J., Papa, F., Ramonet, M., Schimidt, M., Steele, L. P., Tyler, S. C., and White, J.: Contribution of anthropogenic and natural sources to atmospheric methane variability, Nature, 443, 439443, doi:10.1038/nature05132, 2006.

Bousquet, P., Ringeval, B., Pison, I., Dlugokencky, E. J., Brunke, E.G., Carouge, C., Chevallier, F., Fortems-Cheiney, A., Frankenberg, C., Hauglustaine, D. A., Krummel, P. B., Langenfelds, R. L., Ramonet, M., Schmidt, M., Steele, L. P., Szopa, S., Yver, C., Viovy, N., and Ciais, P.: Source attribution of the changes in atmospheric methane for 2006-2008, Atmos. Chem. Phys., 11, 3689-3700, doi:10.5194/acp-11-3689-2011, 2011.

Brass, M. and Röckmann, T.: Continuous-flow isotope ratio mass spectrometry method for carbon and hydrogen isotope measurements on atmospheric methane, Atmos. Meas. Tech., 3, 17071721, doi:10.5194/amt-3-1707-2010, 2010.

Brenninkmeijer, C. A. M., Crutzen, P., Boumard, F., Dauer, T., Dix, B., Ebinghaus, R., Filippi, D., Fischer, H., Franke, H., Frieß, U., Heintzenberg, J., Helleis, F., Hermann, M., Kock, H. H., Koeppel, C., Lelieveld, J., Leuenberger, M., Martinsson, B. G., Miemczyk, S., Moret, H. P., Nguyen, H. N., Nyfeler, P., Oram, D., O’Sullivan, D., Penkett, S., Platt, U., Pupek, M., Ramonet, M., Randa, B., Reichelt, M., Rhee, T. S., Rohwer, J., Rosenfeld, K., Scharffe, D., Schlager, H., Schumann, U., Slemr, F., Sprung, D., Stock, P., Thaler, R., Valentino, F., van Velthoven, P., Waibel, A., Wandel, A., Waschitschek, K., Wiedensohler, A., Xueref-Remy, I., Zahn, A., Zech, U., and Ziereis, H.: Civil Aircraft for the regular investigation of the atmosphere based on an instrumented container: The new CARIBIC system, Atmos. Chem. Phys., 7, 4953-4976, doi:10.5194/acp-7-4953-2007, 2007.

Chen, Y.-H. and Prinn, R. G.: Estimation of atmospheric methane emissions between 1996 and 2001 using a three-dimensional global chemical transport model, J. Geophys. Res., 111, D10307, doi:10.1029/2005JD006058, 2006.

Cunnold, D. M., Steele, L. P., Fraser, P. J., Simmonds, P. G., Prinn, R. G., Weiss, R. F., Porter, L. W., O’Doherty, S., Langenfelds, R. L., Krummel, P. B., Wang, H. J., Emmons, L., Tie, X. X., and Dlugokencky, E. J.: In situ measurements of atmospheric methane at GAGE/AGAGE sites during 1985-2000 and resulting source inferences, J. Geophys. Res., 107, 4225, doi:10.1029/2001JD001226, 2002.

Dlugokencky, E. J., Steele, L. P., Lang, P. M., and Masarie, K. A.: The growth rate and distribution of atmospheric methane, J. Geophys. Res., 99, 17021-17043, 1994.

Dlugokencky, E. J., Houweling, S., Bruhwiler, L., Masarie, K. A., Lang, P. M., Miller, J. B., and Tans, P. P.: Atmospheric methane levels off: Temporary pause or a new steady-state?, Geophys Res. Lett., 30, 1992, doi:10.1029/2003GL018126, 2003.

Dlugokencky, E. J., Bruhwiler, L., White, J. W. C., Emmons, L. K., Novelli, P. C., Montzka, S. A., Masarie, K. A., Lang, P. M., Crotwell, A. M., Miller, J. B., and Gatti, L. V.: Observational constraints on recent increases in the atmospheric $\mathrm{CH}_{4}$ burden, Geophys. Res. Lett., 36, L18803, doi:10.1029/2009GL039780, 2009. 
Dlugokencky, E. J., Nisbet, E. G., Fisher, R. and Lowry, D.: Global atmospheric methane: budget, changes and dangers, Phil. Trans. R. Soc. A, 369, 2058-2072, 2011.

Etheridge, D. M., Steel, L. O., Francey, R. J., and Langenfelds, R. L.: Atmospheric methane between 1000 A.D. and present: Evidence of anthropogenic emissions and climatic variability, J. Geophys. Res., 103, 15979-15993, 1998.

Forster, P., Ramaswamy, V., Artaxo, P., Berntsen, T., Betts, R., Fahey, D. W., Haywood, J., Lean, J., Lowe, D. C., Myhre, G., Nganga, J., Prinn, R., Raga, G., Schulz, M., and Dorland, R. V.: Changes in Atmospheric Constituents and in Radiative Forcing, Climate Change 2007: The Physical Science Basis. Contribution of Working Group I to the Fourth Assessment Report of the Intergovernmental Panel on Climate Change. S. Solomon, D. Qin, M. Manninget al, Cambridge, United Kingdom and New York, NY, USA, Cambridge University Press, 2007.

Francey, R. J., Steele, L. P., Langenfelds, R. L., and Pak, B. C.: High Precision Long-Term Monitoring of Radiatively Active and Related Trace Gases at Surface Sites and from Aircraft in the Southern Hemisphere Atmosphere, J. Atmos. Sci., 56, 279-85, 1999.

Frankenberg, C., Aben, I., Bergamaschi, P., Dlugokencky, E. J., van Hees, R., Houweling, S., van der Meer, P., Snel, R., and Tol, P.: Global column-averaged methane mixing ratios from 2003 to 2009 as derived from SCIAMACHY: Trends and variability, J. Geophys. Res., 116, D04302, doi:10.1029/2010JD014849, 2011.

Fung, I., John, J., Lerner, J., Mattews, E., Prather, M., Steele, L. P., and Fraser, P. J.: Three-dimensional model synthesis of the global methane cycle, J. Geophys. Res., 96, 13033-13065, 1991.

Houweling, S., Röckmann, T., Aben, I., Keppler, F., Krol, M., Meirink, J. F., Dlugokencky, E. J., and Frankenberg, C.: Atmospheric constraints on global emissions of methane from plants, Geophys. Res. Lett., 33, L15821, doi:10.1029/2006GL026162, 022006, 2006.

Ishijima, K., Nakazawa, T., Sugawara, S., Aoki, S., and Saeki, T.: Concentration variations of tropospheric nitrous oxide over Japan, Geophys. Res. Lett., 28, 171-174, 2001.

Ishijima, K., Nakazawa, T., and Aoki, S.: Variations of atmospheric nitrous oxide concentration in the northern and Western Pacific, Tellus, 61B, 408-415, 2009.

Ishijima, K., Patra, P. K., Takigawa, M., Machida, T., Matsueda, H., Sawa, Y., Steele, L. P., Krummel, P. B., Langenfelds, R. L., Aoki, S., and Nakazawa, T.: Stratospheric influence on the seasonal cycle of nitrous oxide in the troposphere as deduced from aircraft observations and model simulations, J. Geophys. Res., 115, D20308, doi:10.1029/2009JD013322, 2010.

Jiang, J. H., Livesey, N. J., Su, H., Neary, L., McConnell, J. C., and Richards, N. A. D.: Connecting surface emissions, convective uplifting, and long-range transport of carbon monoxide in the upper troposphere: New observations from the Aura Microwave Limb Sounder, Geophys. Res. Lett., 34, L18812, doi:10.1029/2007GL030638, 2007.

Lal, S., Chand, D., Venkataramani, S., Appu, K. S., Naja, M., and Patra, P. K.: Trends in methane and sulfur hexafluoride at a tropical coastal site, Thumba $\left(8.6^{\circ} \mathrm{N}, 77^{\circ} \mathrm{E}\right)$, in India, Atmos. Environ., 38, 1145-1151, 2004.
Lloyd, J., Francey, R. J., Mollicone, D., Raupach, M. R., Sogachev, A., Arneth, A., Byers, J. N., Kelliher, F. M., Rebmann, C., Valentini, R., Wong, S.-C., Bauer, G., and Schulze, E.-D.: Vertical profiles, boundary layer budgets, and regional flux estimates for $\mathrm{CO}_{2}$ and its ${ }^{13} \mathrm{C} /{ }^{12} \mathrm{C}$ ratio and for water vapor above a forest/bog mosaic in central Siberia, Global Biogeochem. Cy., 15, 267-284, 2001.

Machida, T., Matsueda, H., Sawa, Y., Nakagawa, Y., Hirotani, K., Kondo, N., Goto, K., Nakazawa, T., Ishikawa, K., and Ogawa, T.: Worldwide measurements of atmospheric $\mathrm{CO}_{2}$ and other trace gas species using commercial airlines, J. Atmos. Ocean. Tech., 25 1744-1754, 2008.

Mak, J. E., Manning, M. R., and Lowe, D. C.: Aircraft observations of $\delta^{13} \mathrm{C}$ of atmospheric methane over the Pacific in August 1991 and 1993: Evidence of an enrichment in ${ }^{13} \mathrm{CH}_{4}$ in the Southern Hemisphere, J. Geophys. Res., 105, 1329-1335, 2000.

Matsueda, $\mathrm{H}$. and Inoue, $\mathrm{H}$. Y.: Measurements of atmospheric $\mathrm{CO}_{2}$ and $\mathrm{CH}_{4}$ using a commercial airliner from 1993 to 1994, Atmos. Environ., 30, 1647-1655, 1996.

Matsueda, H., Inoue, H. Y., Sawa, Y., Tsutsumi, Y., and Ishii, M.: Carbon monoxide in the upper troposphere over the Western Pacific between 1993 and 1996, J. Geophys. Res., 103, 19093$19110,1998$.

Matsueda, H., Inoue, H. Y., and Ishii, M.: Aircraft observations of carbon dioxide at $8-13 \mathrm{~km}$ altitude over the Western Pacific from 1993 to 1999, Tellus, 54B, 1-21, 2002.

Matsueda, H., Machida, T., Sawa, Y., Nakagawa, Y., Hirotani, K., Ikeda, H., Kondo, N., and Goto, K.: Evaluation of atmospheric $\mathrm{CO}_{2}$ measurements from new flask air sampling of JAL airliner observations, Pap. Meteorol. Geophys., 59, 1-17, 2008.

Matthews, E. and Fung, I.: Methane emission from natural wetlands: Global distirbution, area, and environmental characteristics of sources, Global Biogeochem. Cy., 1, 61-86, 1987.

Miller, J. B., Mack, K. A., Dissly, R., White, J. W. C., Dlugokencky, E. J., and Tans, P. P.:, Development of analytical methods and measurements of ${ }^{13} \mathrm{C}^{12} \mathrm{C}$ in atmospheric $\mathrm{CH}_{4}$ from the NOAA Climate Monitoring and Diagnostics Laboratory Global Air Sampling Network, J. Geophys. Res., 107, doi:10.1029/2001JD000630, 2002.

Miller, J. B., Gatti, L. V., d'Amelio, M. T. S., Crotwell, A. M., Dlugokencky, E. J., Bakwin, P., Artaxo, P., and Tans, P. P.: Airborne measurements indicate large methane emissions from the eastern Amazon basin, Geophys. Res. Lett., 34, L10809, doi:10.1029/2006GL029213, 2007.

Miyazaki, K., Patra, P. K., Takigawa, M., Iwasaki, T., and Nakazawa. T.: Global-scale transport of carbon dioxide in the troposphere, J. Geophys. Res., 113, D15301, doi:10.1029/2007JD009557, 2008.

Morimoto, S., Nakazawa, T., Higuchi, K., and Aoki, S.: Latitudinal distribution of atmospheric $\mathrm{CO}_{2}$ sources and sinks inferred by $\delta^{13} \mathrm{C}$ measurements from 1985 to 1991 , J. Geophys. Res., 105, 24315-24326, 2000.

Morimoto, S., Aoki, S., Nakazawa, T., and Yamanouchi, T.: Temporal variations of the carbon isotopic ratio of atmospheric methane observed at Ny Ålesund, Svalbard from 1996 to 2004, Geophys. Res. Lett., 33, L01807, doi:10.1029/2005GL024648, 2006. 
Nakazawa, T., Miyashita, K., Aoki, S., and Tanaka, M.: Temporal and spatial variations of upper tropospheric and lower stratospheric carbon dioxide, Tellus, 43B, 106-117, 1991.

Nakazawa, T., Murayama, S., Miyashita, K., Aoki, S., and Tanaka, M.: Longitudinally different variations of lower tropospheric carbon dioxide concentrations over the North Pacific Ocean, Tellus, 44B, 161-172, 1992.

Nakazawa, T., Machida, T., Tanaka, M., Fujii, Y., Aoki, S., and Watanabe, O.: Differences of the atmospheric $\mathrm{CH}_{4}$ concentration between the Arctic and Antarctic regions in pre-industrial/preagricultural era, Geophys. Res. Lett., 20, 943-946, 1993a.

Nakazawa, T., Morimoto, S., Aoki, S., and Tanaka, M.: Time and space variations of the carbon isotopic ratio of tropospheric carbon dioxide over Japan, Tellus, 45B, 258-274, 1993b.

Nakazawa, T., Morimoto, S., Aoki, S., and Tanaka, M.: Temporal and spatial variaitions of the carbon isotopic ratio of atmospheric carbon dioxide in the Western Pacific region, J. Geophys. Res., 102, 1271-1285, 1997a.

Nakazawa, T., Ishizawa, M., Higuchi, K., and Trivett, N. B. A.: Two curve fitting methods applied to $\mathrm{CO}_{2}$ flask data, Environmetrics, 8, 197-218, 1997b.

Olivier, J. G. J. and Berdowski, J. J. M.: Global emissions sources and sinks, The Climate System. J. Berdowski, R. Guicherit and B. J. Heij, Lisse, The Netherlands, A.A. Balkema Publishers/Swets \& Zeitlinger Publishers, 33-78, 2001.

Onogi, K., Tsutsui, J., Koide, H., Sakamoto, M., Kobayashi, S., Hatsushika, H., Matsumoto, T., Yamazaki, N., Kamahori, H., Takahashi, K., Kadokura, S., Wada, K., Kato, K., Oyama, R., Ose, T., Mannoji, N., and Taira, R.: The JRA-25 Reanalysis, J. Meteorol. Soc. Jpn., 85, 369-432, 2007.

Park, M., Randel, W. J., Kinnison, D. E., Garcia, R. R., and Choi, W.: Seasonal variation of methane, water vapor, and nitrogen oxides near the tropopause: Sattelite observations and model simulations, J. Geophys. Res., 108, D03302, doi:10.1029/2003JD003706, 2004.

Park, M., Randel, W. J., Emmons, L. K., and Liversey, N. J.: Transport pathways of carbon monoxide in the Asian summer monsoon diagnosed from MOZART, J. Geophys. Res., 114, D08303, doi:10.1029/2008JD010621, 2009.

Pataki, D. E., Ehleringer, J. R., Flanagan, L. B., Yakir, D., Bowling, D. R., Still, C. J., Buchmann, N., Kaplan, J. O., and Berry, J. A.: The application and interpretation of Keeling plots in terrestrial carbon cycle research, Global Biogeochem. Cy., 17, 1022, doi:10.1029/2001GB001850, 2003.

Patra, P. K., Takigawa, M., Ishijima, K., Choi, B.-C., Cunnold, D., Dlugokencky, E. J., Fraser, P., Gomez-Pelaez, A. J., Goo, T.-Y., Kim, J.-S., Krummel, P., Langenfelds, R., Meinhardt, F., Mukai, H., O’Doherty, S., Prinn, R. G., Simmonds, P., Steele, P., Tohjima, Y., Tsuboi, K., Uhse, K., Weiss, R., Worthy, D., and Nakazawa, T.: Growth rate, seasonal, synoptic and diurnal variations in lower atmospheric methane and its budget, J. Meteorol. Soc. Jpn., 87, 635-663, doi:10.2151/jmsj.87.635, 2009.

Patra, P. K., Houweling, S., Krol, M., Bousquet, P., Belikov, D., Bergmann, D., Bian, H., Cameron-Smith, P., Chipperfield, M. P., Corbin, K., Fortems-Cheiney, A., Fraser, A., Gloor, E., Hess, P., Ito, A., Kawa, S. R., Law, R. M., Loh, Z., Maksyutov, S., Meng, L., Palmer, P. I., Prinn, R. G., Rigby, M., Saito, R., and Wilson, C.: TransCom model simulations of $\mathrm{CH}_{4}$ and related species: linking transport, surface flux and chemical loss with $\mathrm{CH}_{4}$ vari- ability in the troposphere and lower stratosphere, Atmos. Chem. Phys., 11, 12813-12837, doi:10.5194/acp-11-12813-2011, 2011.

Quay, P. D., King, S. L., Stutsman, J., Wilbur, D. O., Steele, L. P., Fung, I., Gammon, R. H., Brown, T. A., Farwell, G. W., Grootes, P. M., and Schmidt, F. H.: Carbon isotopic composition of atmospheric $\mathrm{CH}_{4}$ : Fossil and biomass burning strengths, Global Biogeochem. Cy., 5, 25-47, 1991.

Quay, P., Stutsman, J., Wilbur, D., Snover, A., Dlugokencky, E., and Brown, T.: The isotopic composition of atmospheric methane, Global Biogeochem. Cy., 13, 445-461, 1999.

Rice, A. L., Gotoh, A. A., Ajie, H. O., and Tyler, S. C.: Highprecision continuous-flow measurement of $\delta^{13} \mathrm{C}$ and $\delta \mathrm{D}$ of atmospheric $\mathrm{CH}_{4}$, Anal. Chem., 73, 4104-4110, 2001.

Rice, A. L., Tyler, S. C., McCarthy, M. C., Boering, K. A., and Atlas, E.: Carbon and hydrogen isotopic compositions of stratospheric methane: 1. High-precision observations from the NASA ER-2 aircraft, J. Geophys. Res., 108, 4460, doi:10.1029/2002JD003042, 2003.

Rigby, M., Prinn, R. G., Fraser, P. J., Simmonds, P. G., Langenfelds, R. L., Huang, J., Cunnold, D. M., Steele, L. P., Krummel, P. B., Weiss, R. F., O’Doherty, S., Salameh, P. K., Wang, H. J., Harth, C. M., Mühle, J., and Porter, L. W.: Renewed growth of atmospheric methane, Geophys. Res. Lett., 35, L22805, doi:10.1029/2008GL036037, 2008.

Rigby, M., Manning, A. J., and Prinn, R. G.: The value of highfrequency, high-precision methane isotopologue measurements for source and sink estimation, J. Geophys. Res., 117, D12312, doi:10.1029/2011JD017384, 2012.

Röckmann, T., Brass, M., Borchers, R., and Engel, A.: The isotopic composition of methane in the stratosphere: high-altitude balloon sample measurements, Atmos. Chem. Phys., 11, 13287-13304, doi:10.5194/acp-11-13287-2011, 2011.

Sasakawa, M., Shimoyama, K., Machida, T., Tsuda, N., Suto, H., Arshinov, M., Davydov, D., Fofonov, A., Krasnov, O., Saeki, T., Koyama, Y., and Maksyutov, S.: Continuous measurements of methane from a tower network over Siberia, Tellus, 62, 403-416, 2010.

Saueressig, G., Bergamaschi, P., Crowley, J. N., Fischer, H., and Harris, G. W.: Carbon kinetic isotope effect in the reaction of $\mathrm{CH}_{4}$ with $\mathrm{Cl}$ atoms, Geophys. Res. Lett., 22, 1225-1228, 1995.

Saueressig, G., Bergamaschi, P., Crowley, J. N., Fischer, H., and Harris, G. W.: D/H kinetic isotope effect in the reaction $\mathrm{CH}_{4}+\mathrm{Cl}$, Geophys. Res. Lett., 23, 3619-3622, 1996.

Saueressig, G., Crowley, J. N., Bergamaschi, P., Brühl, C., Brenninkmeijer, C. A. M., and Fischer, H.: Carbon 13 and D kinetic isotope effects in the reactions of $\mathrm{CH}_{4}$ with $\mathrm{O}\left({ }^{1} \mathrm{D}\right)$ and $\mathrm{OH}$ : New laboratory measurements and their implications for the isotopic composition of stratospheric methane, J. Geophys. Res., 106, 23127-23138, 2001.

Sawa, Y., Machida, T., and Matsueda, H.: Seasonal variations of $\mathrm{CO}_{2}$ near the tropopause observed by commercial aircraft, J. Geophys. Res., 113, D23301, doi:10.1029/2008JD010568, 2008.

Sawa, Y., Machida, T., and Matsueda. H.: Aircraft observation of the seasonal variation in the transport of $\mathrm{CO}_{2}$ in the upper atmosphere, J. Geophys. Res., 117, D05305, doi:10.1029/2011JD016933, 2012.

Schoell, M.: The hydrogen and carbon isotopic composition of methane from natural gases of various origin, Geochim. Cosmochim. Acta, 44, 649-661, 1980. 
Schuck, T. J., Brenninkmeijer, C. A. M., Baker, A. K., Slemr, F., von Velthoven, P. F. J., and Zahn, A.: Greenhouse gas relationships in the Indian summer monsoon plume measured by the CARIBIC passenger aircraft, Atmos. Chem. Phys., 10, 39653984, doi:10.5194/acp-10-3965-2010, 2010.

Spivakovsky, C. M., Logan, J. A., Montzka, S. A., Balkanski, Y. J., Foreman-Fowler, M., Jones, D. B. A., Horowitz, L. W., Fusco, A. C., Brenninkmeijer, C. A. M., Prather, M. J., Wofsy, S. C., and McElroy, M. B.: Three-dimensional climatological distribution of tropospheric $\mathrm{OH}$ : Update and evaluation, J. Geophys. Res., 105, 8931-8980, 2000.

Steele, L. P., Fraser, P. J., Rasmussen, R. A., Khalil, M. A. K., Conway, T. J., Crawford, A. J., Gammon, R. H., Masarie, K. A., and Thoning, K. W.: The global distribution of methane in the troposphere, J. Atmos. Chem., 5, 125-171, 1987.

Streets, D. G., Bond, T. C., Carmichael, G. R., Fernandes, S. D., Fu, Q., He, D., Klimont, Z., Nelson, S. M., Tsai, N. Y., Wang, M. Q., Woo, J.-H. and Yarber, K. F.: An inventory of gaseous and primary aerosol emissions in Asia in the year 2000, J. Geophys. Res., 108, 8809, doi:10.1029/2002JD003093, 2003.

Sudo, K., Takahashi, M., Kurokawa, J., and Akimoto, H.: CHASER: A global chemical model of the troposphere 1. Model description, J. Geophys. Res., 107, doi:10.1029/2001JD001113, 2002.

Sugawara, S., Nakazawa, T., Inoue, G., Machida, T., Mukai, H., Vinnichenko, N. K., and Khattatov, V. U.: Aircraft measurements of the stable carbon isotopic ratio of atmospheric methane over Siberia, Global Biogeochem. Cy., 10, 223-231, 1996.

Sugawara, S., Nakazawa, T., Shirakawa, Y., Kawamura, K., Aoki, S., Machida, T., and Honda, H.: Vertical profile of the carbon isotopic ratio of stratospheric methane over Japan, Geophys. Res. Lett., 24, 2989-2992, 1997.

Takigawa, M., Takahashi, M., and Akiyoshi, H.: Simulation of ozone and other chemical species using a Center for Climate System Research/National Institute for Environmental Studies atmospheric GCM with coupled stratospheric chemistry, J. Geophys. Res., 104, 14003-14018, 1999.

Tanaka, M., Nakazawa, T., and Aoki, S.: Concentrationof Atmospheric Carbon Dioxide over Japan, J. Geophys. Res., 88, 13391344, 1983.

Tanaka, M., Nakazawa, T., and Aoki, S.: Time and space variations of tropospheric carbon dioxide over Japan, Tellus, 39B, 3-12, 1987a.

Tanaka, M., Nakazawa, T., and Aoki, S.: Seasonal and meridional variations of atmospheric carbon dioxide in the lower troposphere of the northern and southern hemispheres, Tellus, 39B, 29-41, 1987b.

Terao, Y., Mukai, H., Nojiri, Y., Machida, T., Tohjima, Y., Saeki, T., and Maksyutov, S.: Interannual variability and trends in atmospheric methane over the Western Pacific from 1994 to 2010, J. Geophys. Res., 116, D14303, doi:10.1029/2010JD015467, 2011.

Tohjima, Y., Machida, T., Utiyama, M., Katsumoto, M., Fujinuma, Y., and Maksyutov, S.: Analysis and presentation of in situ atmospheric methane measurements from Cape Ochi-ishi and Hateruma Island, J. Geophys. Res., 107, 4148, doi:10.1029/2001JD001003, 2002.
Tyler, S. C., Ajie, H. O., Gupta, M. L., Cicerone, R. J., Blake, D. R., and Dlugolencky, E. J.: Stable carbon isotopic composition of atmospheric methane: A comparison of surface level and free tropospheric air, J. Geophys. Res., 104, 13895-13910, 1999.

Tyler, S. C., Ajie, H. O., Rice, A. L., Cicerone, R. J., and Tuazon, E. C.: Experimentally determined kinetic isotope effects in the reaction of $\mathrm{CH}_{4}$ with $\mathrm{Cl}$ : Implications for atmospheric $\mathrm{CH}_{4}$, Geophys. Res. Lett., 27, 1715-1718, 2000.

Tyler, S. C., Rice, A. L., and Ajie, H. O.: Stable isotope ratios in atmospheric $\mathrm{CH}_{4}$ : Implications for seasonal sources and sinks, J. Geophys. Res., 112, D03303, doi:10.1029/2006JD007231, 2007.

Umezawa, T.: A study of global methane cycle based on measurements of its carbon and hydrogen isotopes in the atmosphere, Ph.D. thesis, Graduate school of science, Tohoku University, Sendai, Japan, 2009.

Umezawa, T., Aoki, S., Morimoto, S., and Nakazawa, T.: A highprecision measurement system for carbon and hydrogen isotopic ratios of atmospheric methane and its application to air samples collected in the Western Pacific region, J. Meteorol. Soc. Jpn., 87, 365-379, 2009.

Umezawa, T., Aoki, S., Kim, Y., Morimoto, S., and Nakazawa, T.: Carbon and hydrogen stable isotopic ratios of methane emitted from wetlands and wildfires in Alaska: Aircraft observations and bonfire experiments, J. Geophys. Res., 116, D15305, doi:10.1029/2010JD015545, 2011.

Waliser, D. E. and Gautier, C.: A satellite-derived climatology of the ITCZ, J. Clim., 6, 2162-2174, 1993.

Werner, R. A. and Brand, W. A.: Referencing strategies and techniques in stable isotope ratio analysis, Rapid Comm. Mass Spectrom., 15, 501-519, 2001.

Whiticar, M. and Schaefer, H.: Constraining past global tropospheric methane budgets with carbon and hydrogen isotope ratios in ice, Phil. Trans. R. Soc. A, 365, 1793-1828, doi:1710.1098/rsta.2007.2048, 2007.

Xiao, Y., Jacob, D. J., Wang, J. S., Logan, J. A., Palmer, P. I., Suntharalingam, P., Yantosca, R. M., Sachse, G. W., Blake, D. R., and Streets, D. G.: Constraints on Asian and European sources of methane from $\mathrm{CH}_{4}-\mathrm{C}_{2} \mathrm{H}_{6}-\mathrm{CO}$ correlations in Asian outflow, $\mathrm{J}$. Geophys. Res., 109, D15S16, doi:10.1029/2003JD004475, 2004.

Xiong, X., Houweling, S., Wei, J., Maddy, E., Sun, F., and Barnet, C.: Methane plume over south Asia during the monsoon season: satellite observation and model simulation, Atmos. Chem. Phys., 9, 783-794, doi:10.5194/acp-9-783-2009, 2009.

Yamada, K., Ozaki, Y., Nakagawa, F., Sudo, S., Tsuruta, H., and Yoshida, N.: Hydrogen and carbon isotopic measurements of methane from agricultural combustion: Implications for isotopic signatures of global biomass burning sources, J. Geophys. Res., 111, D16306, doi:10.1029/2005JD006750, 2006.

Yamaji, K., Ohara, T., and Akimoto, H.: A country-specific, highresolution emission inventory for methane from livestock in Asia in 2000, Atmos. Environ., 37, 4393-4406, 2003.

Yan, X., Ohara, T., and Akimoto, H.: Development of regionspecific emission factors and estimation of methane emission from rice fields in the East, Southeast and South Asian countries, Global Change Biol., 9, 237-254, 2003. 
Yashiro, H., Sugawara, S., Sudo, K., Aoki, S., and Nakazawa, T.: Temporal and spatial variations of carbon monoxide over the western part of the Pacific Ocean, J. Geophys. Res., 114, D08305, doi:10.1029/2008JD010876, 2009.

Yoshida, Y., Ota, Y., Eguchi, N., Kikuchi, N., Nobuta, K., Tran, H., Morino, I., and Yokota, T., Retrieval algorithm for $\mathrm{CO}_{2}$ and $\mathrm{CH}_{4}$ column abundances from short-wavelength infrared spectral observations by the Greenhouse gases observing satellite, Atmos. Meas. Tech., 4, 717-734, doi:710.5194/amt-5194-57172011, 2011.
Zhou, L. X., Worthy, D. E. J., Lang, P. M., Ernst, M. K., Zhange, X. C., Wen, Y. P., and Li, J. L.: Ten years of atmospheric methane observations at a high elevation site in Western China, Atmos. Environ., 38, 7041-7054, 2004. 